\title{
Coral reef carbonate budgets and ecological drivers in the central Red Sea - a naturally high temperature and high total alkalinity environment
}

\author{
Anna Roik $^{1, \mathrm{a}}$, Till Röthig ${ }^{1, \mathrm{~b}}$, Claudia Pogoreutz ${ }^{1}$, Vincent Saderne ${ }^{1}$, and Christian R. Voolstra ${ }^{1}$ \\ ${ }^{1}$ Red Sea Research Center, King Abdullah University of Science and Technology, 23955 Thuwal, Saudi Arabia \\ ${ }^{a}$ current address: Marine Microbiology, GEOMAR Helmholtz Centre for Ocean Research, 24105 Kiel, Germany \\ b current address: Aquatic Research Facility, Environmental Sustainability Research Centre, University of Derby, \\ Kedleston Road, Derby, DE22 1GB, UK
}

Correspondence: Christian R. Voolstra (christian.voolstra@kaust.edu.sa) and Anna Roik (aroik@geomar.de)

Received: 30 January 2018 - Discussion started: 28 February 2018

Revised: 16 September 2018 - Accepted: 28 September 2018 - Published: 26 October 2018

\begin{abstract}
The structural framework provided by corals is crucial for reef ecosystem function and services, but high seawater temperatures can be detrimental to the calcification capacity of reef-building organisms. The Red Sea is very warm, but total alkalinity (TA) is naturally high and beneficial for reef accretion. To date, we know little about how such detrimental and beneficial abiotic factors affect each other and the balance between calcification and erosion on Red Sea coral reefs, i.e., overall reef growth, in this unique ocean basin. To provide estimates of present-day reef growth dynamics in the central Red Sea, we measured two metrics of reef growth, i.e., in situ net-accretion/-erosion rates $\left(G_{\text {net }}\right)$ determined by deployment of limestone blocks and ecosystem-scale carbonate budgets $\left(G_{\text {budget }}\right)$, along a crossshelf gradient $(25 \mathrm{~km}$, encompassing nearshore, midshore, and offshore reefs). Along this gradient, we assessed multiple abiotic (i.e., temperature, salinity, diurnal $\mathrm{pH}$ fluctuation, inorganic nutrients, and TA) and biotic (i.e., calcifier and epilithic bioeroder communities) variables. Both reef growth metrics revealed similar patterns from nearshore to offshore: net-erosive, neutral, and net-accretion states. The average cross-shelf $G_{\text {budget }}$ was $0.66 \mathrm{~kg} \mathrm{CaCO}_{3} \mathrm{~m}^{-2} \mathrm{yr}^{-1}$, with the highest budget of $2.44 \mathrm{~kg} \mathrm{CaCO}_{3} \mathrm{~m}^{-2} \mathrm{yr}^{-1}$ measured in the offshore reef. These data are comparable to the contemporary $G_{\text {budgets }}$ from the western Atlantic and Indian oceans, but lie well below "optimal reef production" (5-10 $\mathrm{kg} \mathrm{CaCO}_{3} \mathrm{~m}^{-2} \mathrm{yr}^{-1}$ ) and below maxima recently recorded in remote high coral cover reef sites. However, the erosive forces observed in the Red Sea nearshore
\end{abstract}

reef contributed less than observed elsewhere. A higher TA accompanied reef growth across the shelf gradient, whereas stronger diurnal $\mathrm{pH}$ fluctuations were associated with negative carbonate budgets. Noteworthy for this oligotrophic region was the positive effect of phosphate, which is a central micronutrient for reef building corals. While parrotfish contributed substantially to bioerosion, our dataset also highlights coralline algae as important local reef builders. Altogether, our study establishes a baseline for reef growth in the central Red Sea that should be useful in assessing trajectories of reef growth capacity under current and future ocean scenarios.

\section{Introduction}

Coral reef growth is mostly limited to warm, aragonitesaturated, and oligotrophic tropical oceans and is pivotal for reef ecosystem functioning (Buddemeier, 1997; Kleypas et al., 1999). The coral reef framework not only maintains a remarkable biodiversity, but also provides highly valuable ecosystem services that include food supply and coastal protection, among others (Moberg and Folke, 1999; ReakaKudla, 1997). Biogenic calcification, erosion, and dissolution contribute to the formation of the reef framework constructed of calcium carbonate $\left(\mathrm{CaCO}_{3}\right.$, mainly aragonite). The balance of carbonate loss and accretion is influenced by biotic and abiotic factors. On a reef scale, the main antagonists are calcifying benthic communities on the one hand, 
such as scleractinian corals and coralline algal crusts, and grazing and endolithic bioeroders on the other hand, such as parrotfish, sea urchins, microbioeroding chlorophytes, boring sponges, and other macroborers (Glynn, 1997; Hutchings, 1986; Perry et al., 2008; Tribollet and Golubic, 2011). The export or loss of carbonate as sediments is considered an essential part, in particular in the wider geomorphic perspective of reef carbonate production states (Cyronak et al., 2013; Perry et al., 2008, 2017). Temperature and carbonate chemistry parameters (e.g., $\mathrm{pH}$, total alkalinity: TA, aragonite saturation state: $\Omega_{\mathrm{a}}$, and $p \mathrm{CO}_{2}$ ) have been identified as important players in regulating these carbonate accretion and erosion processes (Albright et al., 2018; Schönberg et al., 2017). Furthermore, different light regimes across depths, water flow, and wave exposure can alter the rates of reef-formation processes (Dullo et al., 1995; Glynn and Manzello, 2015; Kleypas et al., 2001).

Reef growth is maintained when reef calcification produces more $\mathrm{CaCO}_{3}$ than is being removed, and it depends largely on the ability of benthic calcifiers to precipitate calcium carbonate from seawater (e.g., Langdon et al., 2000; Tambutté et al., 2011). TA and $\Omega_{\mathrm{a}}$ positively correlate with calcification rates (Marubini et al., 2008; Schneider and Erez, 2006), and while calcification rates of corals and coralline algae increase with higher temperature, they have upper thermal limits (Jokiel and Coles, 1990; Marshall and Clode, 2004; Vásquez-Elizondo and Enríquez, 2016). Today's oceans are warming and high temperatures are beginning to exceed the thermal optima of calcifying organisms, thereby slowing down or interrupting calcification (e.g., Carricart-Ganivet et al., 2012; Death et al., 2009). At the same time, ocean acidification decreases the oceans' $\mathrm{pH}$ and $\Omega_{\mathrm{a}}$ (Orr et al., 2005). Arguably, calcification under these conditions becomes energetically costlier (Cai et al., 2016; Cohen and Holcomb, 2009; Strahl et al., 2015; Waldbusser et al., 2016). In addition, ocean acidification stimulates destructive processes, for instance the proliferation of bioeroding endolithic organisms (e.g., Enochs, 2015; Fang et al., 2013; Tribollet et al., 2009). Apart from that, locally impaired reef growth due to an increased intensity or frequency of extreme climate events (Eakin, 2001; Schuhmacher et al., 2005), human impacts including pollution and eutrophication (Chazottes et al., 2002; Edinger et al., 2000), and other ecological events such as population outbreaks of grazing sea urchins or crown-of-thorn starfish that feed on coral can induce reef framework degradation (Bak, 1994; Pisapia et al., 2016; Uthicke et al., 2015).

A number of studies have employed experimental limestone blocks cut from coral skeletons to study reef growth processes (Chazottes et al., 1995; Kiene and Hutchings, 1994; Silbiger et al., 2014; Tribollet and Golubic, 2005). Deployment of such blocks in a reef captures the endolithic and epilithic accretion and erosion agents and forces, simultaneously allowing for the measurement of net-accretion and net-erosion rates. In particular, these studies have provided insight into the colonization progression and activity of endolithic micro- and macro-organisms. To comparatively assess the persistence of the reef framework on the ecosystem scale, a census-based reef carbonate budget (ReefBud$g e t)$ approach that integrates reef site-specific ecological data into the calculation of the erosion-accretion balance was introduced recently (Kennedy et al., 2013; Perry et al., 2012, 2015). Using the ReefBudget approach, a study determined that $37 \%$ of all current reefs that were investigated are in a net-erosive state (Perry et al., 2013). For the Caribbean, it revealed a $50 \%$ decrease in reef growth compared to historical mid- to late-Holocene reef growth (Perry et al., 2013). Furthermore, the use of carbonate budgets provided valuable insight into the reef growth trajectories in the Seychelles, where surveys conducted since the 1990s provide important ecological baseline data that were employed in reef growth calculations (Januchowski-Hartley et al., 2017). Most recently, carbonate budget data were used to explore the relation of vertical reef growth potential and trends in sea level rise, suggesting that reef submergence poses a threat as long as climate-driven and human-made perturbations persist (Perry et al., 2018). Other studies highlight the susceptibility of marginal coral reefs to ocean warming and acidification (Couce et al., 2012). Such marginal reefs are found in the eastern Pacific or in the Middle East in the Persian/Arabian Gulf, where reefs exist at their environmental limits, e.g., at low $\mathrm{pH}$ or high temperatures, respectively (Bates et al., 2010; Manzello, 2010; Riegl, 2003; Sheppard and Loughland, 2002).

Although the Red Sea features high sea surface temperatures that exceed thermal thresholds of tropical corals elsewhere (Kleypas et al., 1999; Osman et al., 2018), it supports a remarkable coral reef framework along its entire coastline (Riegl et al., 2012). However, coral skeleton core samples indicate that calcification rates have been declining over the past decades, which has been widely attributed to ocean warming (Cantin et al., 2010). In this regard Red Sea coral reefs are on a similar trajectory as other coral reefs under global ocean warming (Bak et al., 2009; Cooper et al., 2008). In the central and southern Red Sea, present-day data show reduced calcification rates of corals and calcifying crusts when temperatures peak during summer (Roik et al., 2015; Sawall et al., 2015). While increasing temperatures are seemingly stressful and energetically demanding for reef calcifiers, high TA values, as found in the Red Sea ( $\sim 2400 \mu \mathrm{mol} \mathrm{kg}{ }^{-1}$, Metzl et al., 1989), are indicative of a putatively beneficial environment for calcification (Albright et al., 2016; Langdon et al., 2000; Tambutté et al., 2011). At present, little is known about the reef-scale carbonate budgets of Red Sea coral reefs (Jones et al., 2015). Apart from one early assessment of reef growth capacity for a highlatitude reef in the Gulf of Aqaba (GoA, northern Red Sea) that considered both calcification and bioerosion/dissolution rates (Dullo et al., 1996), studies only report calcification rates (e.g., Cantin et al., 2010; Heiss, 1995; Roik et al., 2015; 


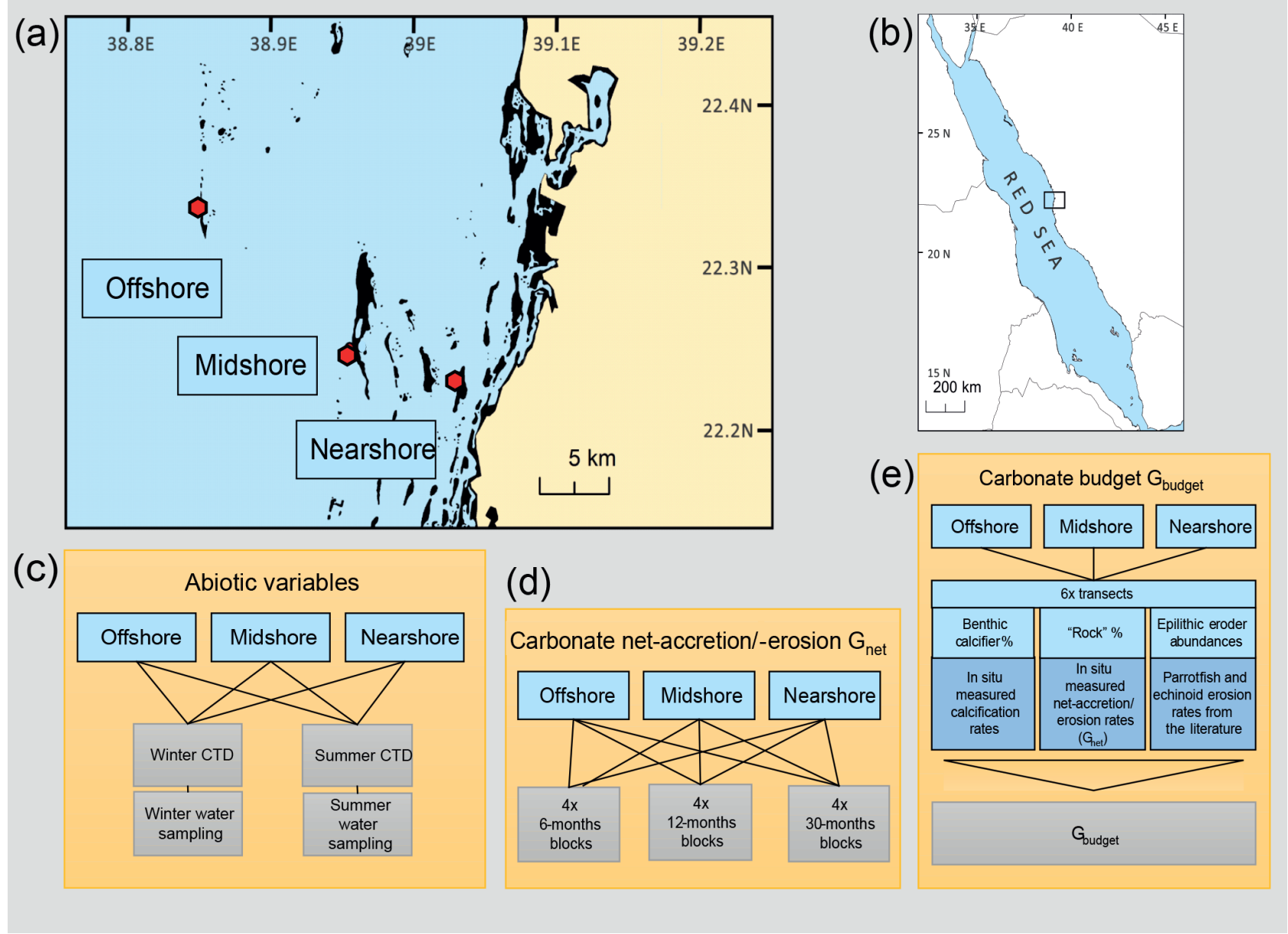

Figure 1. Design of studies and reef sites in the central Red Sea. Maps (a) and (b) indicate geographic location and the study sites along a cross-shelf gradient. Schemes in (c)- (e) summarize the study designs for the assessment of the two reef growth metrics, $G_{\text {net }}$ and $G_{\text {budget }}$, and the characterization of the abiotic environments in the central Red Sea. Maps have been adapted from Roik et al. (2015).

Sawall and Al-Sofyani, 2015) or focus on bioerosion generally caused by one group of bioeroders (Alwany et al., 2009; Kleemann, 2001; Mokady et al., 1996). Therefore, we set out to determine reef growth in central Red Sea coral reefs and evaluate the biotic and abiotic drivers. We show and compare two reef growth metrics: $G_{\text {net }}$ and $G_{\text {budget }}$. We present net-accretion/-erosion rates $\left(G_{\text {net }}\right)$ measured in situ using limestone blocks deployed in the reefs, which simultaneously capture the rates of epilithic accretion and epilithic and endolithic bioerosion. We also apply a census-based approach adapted from the ReefBudget protocol (Perry et al., 2012) to estimate reef growth on an ecosystem scale, as the net carbonate production state or carbonate budget ( $\left.G_{\text {budget }}\right)$. Our study provides a broad and first insight into reef growth dynamics and a comparative baseline to further assess the effects of environmental change on reef growth in the central Red Sea.

\section{Material and methods}

\subsection{Study sites and environmental monitoring}

Study sites are located in the Saudi Arabian central Red Sea along an environmental cross-shelf gradient, described in detail in Roik et al. (2015) and Roik et al. (2016). Data for this study were collected at three sites: an offshore forereef at $\sim 25 \mathrm{~km}$ distance from the coastline $\left(22^{\circ} 20.456 \mathrm{~N}\right.$, $38^{\circ} 51.127 \mathrm{E}$; "Shi'b Nazar"), a midshore forereef at $\sim 10 \mathrm{~km}$ distance $\left(22^{\circ} 15.100 \mathrm{~N}, 38^{\circ} 57.386 \mathrm{E}\right.$; "Al Fahal"), and a nearshore forereef $\left(22^{\circ} 13.974 \mathrm{~N}, 39^{\circ} 01.760 \mathrm{E}\right.$; "Inner Fsar") at $\sim 3 \mathrm{~km}$ distance to the shore (Fig. 1a, b). All sampling stations were located between 7.5 and $9 \mathrm{~m}$ depth. In the following, reef sites are referred to as "offshore", "midshore", and "nearshore", respectively. Abiotic variables were measured during "winter" and "summer" 2014. CTD data were collected continuously during "winter" (9 February7 April 2014) and "summer" (19 June-23 October 2014). At each station, seawater samples were collected on SCUBA for 
5-6 consecutive weeks during each of the seasons to determine inorganic nutrients, i.e., nitrate and nitrite $\left(\mathrm{NO}_{3}^{-}\right.$and $\left.\mathrm{NO}_{2}^{-}\right)$, ammonia $\left(\mathrm{NH}_{4}^{+}\right)$, phosphate $\left(\mathrm{PO}_{4}^{3-}\right)$, and total alkalinity (TA) (Fig. 1c and Table S1 in the Supplement).

\subsection{Net-accretion/-erosion rates of limestone blocks}

Net-accretion/-erosion rates $\left(G_{\text {net }}\right.$, Table 1$)$ were assessed using a "limestone block assay". Blocks cut from "coral stone" limestone were purchased from a local building material supplier in Jeddah, KSA. Each block was fixed with one stainless steel bolt to aluminum racks permanently deployed at the monitoring station of each reef site (a total of 36 blocks, $n=4$, Fig. S1 in the Supplement). The blocks were oriented in parallel to the reef slope with one side facing up while the other side was facing down towards the reef. Block dimensions were $100 \times 100 \times 21 \mathrm{~mm}$ with an average density of $\rho=2.3 \mathrm{~kg} \mathrm{~L}^{-1}$. Blocks were dry-weighed before and after deployment on the reefs (Mettler Toledo XS2002S, readability $=10 \mathrm{mg}$ ). Before weighing, the blocks were autoclaved and dried in a climate chamber (BINDER, Tuttlingen, Germany) at $40^{\circ} \mathrm{C}$ for a week. Four replicate blocks were deployed at the reef sites for three different exposure periods each (Fig. 1d) to measure natural processes of calcification and erosion. Exposure periods were 6 months (September 2012-March 2013), 12 months (June 2013-June 2014), and 30 months each (January 2013-June 2015). We measured a total of 12 blocks and all blocks were measured only once. Upon recovery, the blocks were treated with $10 \%$ bleach for $24-36 \mathrm{~h}$ and rinsed with deionized water to remove organic material and any residual salts. $G_{\text {net }}$ were expressed as normalized differences of pre-deployment and post-deployment weights $\left(\mathrm{kg} \mathrm{CaCO}_{3} \mathrm{~m}^{-2} \mathrm{yr}^{-1}\right)$ (Table 1).

\subsection{Biotic parameters}

To assess coral reef benthic calcifier and epilithic bioeroder communities (as input data for the reef carbonate budgets), we conducted in situ surveys on SCUBA along the crossshelf gradient at each of our study sites.

\subsubsection{Benthic community composition}

Community composition and coverage of coral reef calcifying groups were assessed in six replicate transects per site using the rugosity transect (Perry et al., 2012) as detailed in Roik et al. (2015). From these surveys we extracted data on benthic calcifiers (\% cover total hard coral, \% hard coral morphs (branching, encrusting, massive, and platy/foliose), $\%$ major reef-building coral families (Acroporidae, Pocilloporidae, and Poritidae), \% cover calcareous crusts, \% recently dead coral, and \% rock surface area for carbonate budget calculations (Table S2). In addition, benthic rugosity was assessed in the same transects according to the chain-andtape method ( $n=6$, Perry et al., 2012).

\subsubsection{Epilithic bioeroder/grazer populations along the cross-shelf gradient}

For each reef site, we surveyed abundances and size classes of the two main groups of coral reef framework epilithic bioerorders, parrotfish (Scaridae) (Bellwood, 1995; Bruggemann et al., 1996) and sea urchins (Echinoidea) (Bak, 1994). Surveys were conducted on SCUBA using stationary plots (adapted from Bannerot and Bohnsack, 1986, Text S1 in the Supplement) and line transects ( $n=6$ per site), respectively. Briefly, abundances of parrotfish and sea urchins were assessed for different size classes. Abundances for all prevalent parrotfish species were assessed in six size classes, based on estimated fork length (FL; FL size classes: $1=$ $5-14,2=15-24,3=25-34,4=35-44,5=45-70$, and $6>70 \mathrm{~cm}$ ). We focused on the most abundant bioeroding parrotfish species in the Red Sea, which encompassed two herbivorous functional groups: excavators and scrapers (Green and Bellwood, 2009). Most abundant across study sites were the excavators Chlorurus gibbus, Scarus ghobban, and $\mathrm{Ce}$ toscarus bicolor, and the scrapers Scarus frenatus, Chlorurus sordidus, Scarus niger, and Scarus ferrugenius, following Alwany et al. (2009). Additionally, we counted Hipposcarus harid, which occurred frequently at the study sites, along with members of the genus Scarus that could not be identified to the species level and were therefore pooled in the category "Other Scarus". Both H. harid and Scarus spp. were broadly categorized as scrapers (Green and Bellwood, 2009). The sea urchin census targeted five size classes of the four most common bioerosive genera Diadema, Echinometra, Echinostrephus, and Eucidaris, based on urchin diameter (size classes $1=0-20,2=21-40,3=41-60,4=61-$ 80 , and $5=81-100 \mathrm{~mm}$, Table S7). For details on the field surveys and data treatment for biomass conversion, refer to the Supplement (Text S1 and references therein).

\subsection{Reef carbonate budgets}

Ecosystem-scale reef carbonate budgets, $G_{\text {budget }}$ $\left(\mathrm{kg} \mathrm{CaCO}_{3} \mathrm{~m}^{-2} \mathrm{yr}^{-1}\right)$, were determined following the census-based ReefBudget approach by Perry et al. (2012) (Fig. 1e and Table 1). $G_{\text {budget }}$ incorporates local census data, site-specific net-accretion/-erosion data $\left(G_{\text {net }}\right.$ over 30 months), and calcification data (buoyant weight measurements) collected for this and a previous study (Roik et al., 2015). Importantly, the approach incorporates epilithic bioerosion, which is based on abundance rather than bite or erosion rates; therefore, parrotfish and sea urchin census data collected in this study were employed in the ReefBudget calculations using bite and erosion rates from the literature (Alwany et al., 2009; Perry et al., 2012). In summary, site-specific benthic calcification rates $\left(G_{\text {benthos }}, \quad \mathrm{kg} \mathrm{CaCO}_{3} \mathrm{~m}^{-2} \mathrm{yr}^{-1}\right)$, net-accretion/erosion rates of reef "rock" surface area ( $G_{\text {netbenthos, }}$ $\mathrm{kg} \mathrm{CaCO}_{3} \mathrm{~m}^{-2} \mathrm{yr}^{-1}$ ), and epilithic erosion rates by sea 
Table 1. Glossary of reef growth metrics.

\begin{tabular}{lll}
\hline Metric & Description & Input data for calculation of the metric \\
\hline$G_{\text {net }}$ & $\begin{array}{l}\text { Site-specific net-accretion/-erosion rates (internal and } \\
\text { epilithic) measured in situ using limestone blocks }\end{array}$ & - \\
\hline$G_{\text {budget }}^{*}$ & $\begin{array}{l}\text { Ecosystem-scale census-based carbonate budget of } \\
\text { a reef site }\end{array}$ & $G_{\text {benthos }}, G_{\text {netbenthos }}, E_{\text {echino }}, E_{\text {parrot }}$ \\
\hline$G_{\text {benthos }}$ & $\begin{array}{l}\text { Census-based calcification rate of benthic calcifier } \\
\text { community (corals and coralline algae) per reef site }\end{array}$ & $\begin{array}{l}\text { Site-specific benthic calcification rates (collated from } \\
\text { this study and from Roik et al. 2015) }\end{array}$ \\
\hline$G_{\text {netbenthos }}$ & $\begin{array}{l}\text { Census-based net-accretion/-erosion rates of } \\
\text { reef "rock" surface area per reef site }\end{array}$ & $\begin{array}{l}\text { Site-specific net-accretion/-erosion rates measured in } \\
\text { this study using limestone blocks }\left(G_{\text {net }}\right)\end{array}$ \\
\hline$E_{\text {echino }}$ & $\begin{array}{l}\text { Census-based echinoid (sea urchin) erosion rates } \\
\text { per reef site }\end{array}$ & $\begin{array}{l}\text { Genus- and size-specific erosion rates for sea urchins } \\
\text { from the literature }\end{array}$ \\
\hline$E_{\text {parrot }}$ & Census-based parrotfish erosion rate per reef site & $\begin{array}{l}\text { Genus- and size-specific erosion rates for parrotfish } \\
\text { from the literature }\end{array}$ \\
\hline
\end{tabular}

* The method of $G_{\text {budget }}$ calculation is described in the Supplement (please refer to Text S1).

urchins ( $\left.E_{\text {echino, }}, \mathrm{kg} \mathrm{CaCO}_{3} \mathrm{~m}^{-2} \mathrm{yr}^{-1}\right)$ and parrotfish $\left(E_{\text {parrot }}, \mathrm{kgCaCO}_{3} \mathrm{~m}^{-2} \mathrm{yr}^{-1}\right.$ ) were determined for the $G_{\text {budget }}$ calculations (Figs. 1e and 3a). A detailed account of Red Sea specific calculations and modifications of the ReefBudget approach employed in this study are outlined in the Supplement (Text S1, Equation box S1-S3, and Tables S2-S8).

\subsection{Abiotic parameters}

\subsubsection{Continuous data: temperature, salinity, and diurnal $\mathrm{pH}$ variation}

Factory-calibrated conductivity-temperature-depth loggers (CTDs, SBE 16plusV2 SEACAT, RS-232, Sea-Bird Electronics, Bellevue, WA, USA) were deployed at the sampling stations on tripods at $\sim 0.5 \mathrm{~m}$ above the reef to collect time series data of temperature, salinity, and $\mathrm{pH}_{\mathrm{NBS}}$ at hourly intervals. The $\mathrm{pH}$ probes (SBE 18/27, Sea-Bird Electronics) were factory-calibrated before the winter deployment (9 February-7 April 2014). Calibrations were verified using NBS-scale standard buffers (pH 7 and 10, Fixanal, Fluka Analytics, Sigma Aldrich, Germany) before the winter and the summer deployment (19 June-23 October 2014).

\subsubsection{Seawater samples: inorganic nutrients and total alkalinity}

Seawater samples were collected on SCUBA at each of the stations using $4 \mathrm{~L}$ collection containers (Table S1). Simultaneously, $60 \mathrm{~mL}$ seawater samples were taken through a $0.45 \mu \mathrm{m}$ syringe filter for TA measurements. Seawater samples for inorganic nutrient analyses and TA measurements were transported on ice in the dark and were processed on the same day. Samples were filtered over GF/F filters $(0.7 \mu \mathrm{m}$,
Table 2. Net-accretion/-erosion rates $G_{\text {net }}\left(\mathrm{kg} \mathrm{CaCO}_{3} \mathrm{~m}^{-2} \mathrm{yr}^{-1}\right)$ in coral reefs along a cross-shelf gradient in the central Red Sea. $G_{\text {net }}$ was calculated using weight gain/loss of limestone blocks that were deployed in the reefs. For each deployment duration, 6, 12, and 30 months, a set of four replicate blocks was used. Each block was measured once. Provided are means per reef site and standard deviations (in brackets).

\begin{tabular}{lrrr}
\hline \multirow{2}{*}{$G_{\text {net }}$} & \multicolumn{3}{c}{ Deployment time (months) } \\
\cline { 2 - 4 } Reef site & 6 & 12 & 30 \\
\hline Offshore & $0.14(0.11)$ & $0.08(0.09)$ & $0.37(0.08)$ \\
Midshore & $0.11(0.16)$ & $0.01(0.07)$ & $0.06(0.12)$ \\
Nearshore & $0.11(0.07)$ & $-0.61(0.49)$ & $-0.96(0.75)$ \\
\hline
\end{tabular}

Whatman, UK) and filtrates were frozen at $-20^{\circ} \mathrm{C}$ until analysis. The inorganic nutrient content $\left(\mathrm{NO}_{3}^{-}\right.$and $\mathrm{NO}_{2}^{-}$, $\mathrm{NH}_{4}^{+}$, and $\mathrm{PO}_{4}^{3-}$ ) was determined using standard colorimetric tests and a Quick-Chem 8000 AutoAnalyzer (Zellweger Analysis, Inc.). TA samples were analyzed within 2-4h after collection using an automated acidimetric titration system (Titrando 888, Metrohm AG, Switzerland). Gran-type titrations were performed with a $0.01 \mathrm{M} \mathrm{HCl}$ (prepared from $0.1 \mathrm{HCl}$ standard, Fluka Analytics) at an average accuracy of $\pm 9 \mu \mathrm{mol} \mathrm{kg}^{-1}$ (standard deviation of triplicate measurements).

\subsection{Statistical analyses}

\subsubsection{Net-accretion/-erosion rates and carbonate budgets}

$G_{\text {net }}$ data (Table 2) were tested for effects of the factors "reef" (fixed factor: nearshore, midshore, and offshore) and 
"deployment time" (random factor: 6, 12, and 30 months). A univariate 2-factorial PERMANOVA was performed on $\log _{n}(x)$ transformed data (i.e., $\log _{n}\left(x+1-\min \left(x_{1-n}\right)\right)$ as data contained negative and near-zero values). A Euclidian distance matrix and 9999 permutations of residuals under a reduced model and type III partial sum of squares were employed. Pair-wise tests followed where applicable (PRIMERE V6, Table S9).

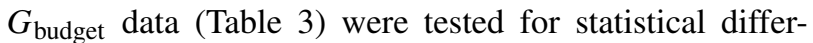
ences between the reef sites (fixed factor: nearshore, midshore, and offshore) using a 1-factorial ANOVA. In parallel, $G_{\text {benthos }}$ was tested using a 1 -factorial ANOVA with $\log _{10}$ transformed data, while non-parametric Kruskal-Wallis tests were employed for non-transformed $G_{\text {netbenthos }}, E_{\text {echino, }}$, and $E_{\text {parrot }}$ data. Tukey's HSD post hoc tests or Dunn's multiple comparisons followed where applicable (Table S10). Assumptions about parametric distribution of data were evaluated using the Shapiro-Wilk normality test. Statistical tests were performed as implemented in R (R Core Team, 2013).

\subsubsection{Abiotic parameters}

All abiotic data were summarized as means and standard deviations per reef and season and over each season and boxplots were generated. Diurnal $\mathrm{pH}$ variation was extracted from the continuous data as the $\mathrm{pH}_{\mathrm{NBS}}$ standard deviation per day. Outliers were detected and removed from the TA data. All outliers (data points beyond the upper boxplot 1.5 IQR) clustered to 1 sampling day (23 June 2014), which we considered an artifact of the chemical analysis, and the outliers from this day were removed. All continuous abiotic variables and inorganic nutrients $\left(\mathrm{PO}_{4}^{3-}\right.$ after square-root transformation) fulfilled parametric assumptions and were evaluated using univariate 2-factorial ANOVAs testing the factors "reef" (nearshore, midshore, and offshore) and "season" (winter and summer). TA data were square-root transformed, which improved symmetry of data (Anderson et al., 2008), and tested under the same 2-factorial design, as outlined above, using a PERMANOVA (Euclidian resemblance matrix and 9999 permutations of residuals under a reduced model and type II partial sums of squares). Within each significant factor, Tukey's HSD post hoc tests or PERMANOVA integrated pair-wise tests followed (Tables S11 and S12). Assumptions were evaluated by histograms and the Shapiro-Wilk normality test. Statistical tests and outlier detection were performed in R or PRIMER-E V6.

\subsubsection{Abiotic-biotic correlations}

To evaluate the relationship of abiotic and biotic predictors of $G_{\text {net }}$ and $G_{\text {budget }}$, Spearman rank correlation coefficients were obtained for the predictor variables (at a confidence level of $95 \%$ ) using cor.test in R (R Core Team, 2013; Wickham and Chang, 2015). $P$-values were adjusted using p.adjust in R employing the Benjamini-Hochberg method.
Correlations were performed using $G_{\text {net }}$ data obtained in the 30-month measurements from the reef sites (nearshore, midshore, and offshore) (Tables 5 and S13). Predictor variables were the site-specific means of CTD measured variables (temperature, salinity, and diurnal $\mathrm{pH}$ variation), means of inorganic nutrients $\left(\mathrm{NO}_{3}^{-}\right.$and $\mathrm{NO}_{2}^{-}, \mathrm{NH}_{4}^{+}$, and $\left.\mathrm{PO}_{4}^{3-}\right)$, and TA. Biotic predictors were variables that likely impacted the limestone blocks, i.e., parrotfish abundances, sea urchin abundances, calcareous crusts cover, and algal and sponge cover. Since we did not observe any coral recruits of substantial size on the blocks, we did not include \% coral cover and related variables in the correlations.

$G_{\text {budget }}$ correlations included all the above-mentioned abiotic variables and 13 biotic transect variables (i.e., parrotfish abundances, sea urchin abundances, \% branching coral, $\%$ encrusting coral $\%$ massive coral, $\%$ platy/foliose coral, $\%$ Acroporidae, \% Pocilloporidae, \% Poritidae, \% total hard coral cover, calcareous crusts cover, algal and sponge cover, and rugosity). Prior to analysis, some of the predictors (i.e., $\%$ platy/foliose corals and \% Poritidae) were $\log _{10}(x+1)$ transformed to improve the symmetry in their distributions (Tables 5 and S14).

\section{Results}

\subsection{Net-accretion/-erosion rates of limestone blocks}

Net-accretion/-erosion rates $G_{\text {net }}$ were measured in limestone block assays over periods of 6,12 , and 30 months in the reef sites along the cross-shelf gradient. These measurements represent the result of calcification and bioerosion processes impacting the deployed limestone blocks. Visible traces of boring endolithic fauna were only found on the surface of blocks recovered after 12 and 30 months as presented in Fig. 2a-f. A brief visual inspection of the block surfaces after retrieval showed colonization by coralline algae, bryozoans, boring sponges, small-size boring worms and clams, as well as parrotfish bite marks. No coral recruits were noticed by the unaided eye. Further analyses of the established presence of calcifying and bioeroding communities were not within the scope of this study. $G_{\text {net }}$ based on the 30-month deployment of blocks ranged between -0.96 and $0.37 \mathrm{~kg} \mathrm{CaCO}_{3} \mathrm{~m}^{-2} \mathrm{yr}^{-1}$ (Table 2). $G_{\text {net }}$ for 12- and 30month blocks were negative on the nearshore reef (between -0.61 and $-0.96 \mathrm{~kg} \mathrm{CaCO}_{3} \mathrm{~m}^{-2} \mathrm{yr}^{-1}$; i.e., net erosion is apparent), slightly positive on the midshore reef $(0.01-0.06 \mathrm{~kg}$ $\mathrm{CaCO}_{3} \mathrm{~m}^{-2} \mathrm{yr}^{-1}$, i.e., an almost neutral carbonate production state), and positive on the offshore reef (up to $0.37 \mathrm{~kg}$ $\mathrm{CaCO}_{3} \mathrm{~m}^{-2} \mathrm{yr}^{-1}$, i.e., net accretion of the reef framework). Deployment times had a significant effect on the variability of $G_{\text {net }}$ (Pseudo- $F=5.9, p_{\text {PERMANOVA }}<0.01$, Table S9). As expected, accretion/erosion was overall higher when measured over the longer deployment period (Fig. $2 \mathrm{~g}$ ) in comparison to the shorter deployment times, reflecting the con- 
Table 3. Reef carbonate budgets and contributing biotic variables $\left(\mathrm{kg} \mathrm{CaCO}_{3} \mathrm{~m}^{-2} \mathrm{yr}^{-1}\right)$ along a cross-shelf gradient in the central Red Sea. Calcification rates of benthic calcifiers $\left(G_{\text {benthos }}\right)$, net-accretion/-erosion rates of the reef "rock" surface area $\left(G_{\text {netbenthos }}\right)$, and the erosion rates of echinoids and parrotfish $\left(E_{\text {echino }}, E_{\text {parrot }}\right)$ contribute to the total carbonate budget $\left(G_{\text {budget }}\right)$ at a reef site. Shown are means per site and standard deviations (in brackets).

\begin{tabular}{lrrrrr}
\hline Reef & $G_{\text {budget }}$ & $G_{\text {benthos }}$ & $G_{\text {netbenthos }}$ & $E_{\text {echino }}$ & $E_{\text {parrot }}$ \\
\hline Offshore & $2.44(1.03)$ & $2.81(0.65)$ & $0.09(0.02)$ & $-0.02(0)$ & $-0.44(0.7)$ \\
Midshore & $1.02(0.35)$ & $1.76(0.24)$ & $0.01(0)$ & $-0.02(0.04)$ & $-0.73(0.31)$ \\
Nearshore & $-1.48(1.75)$ & $0.43(0.15)$ & $-0.31(0.13)$ & $-0.23(0.19)$ & $-1.36(1.89)$ \\
\hline
\end{tabular}

Table 4. Abiotic parameters relevant for reef growth at the study sites along a cross-shelf gradient in the central Red Sea. Temperature (Temp), salinity (Sal), and diurnal $\mathrm{pH}$ variation (diurnal SDs of $\mathrm{pH}_{\mathrm{NBS}}$ measurements) were continuously measured using in situ probes (CTDs). Weekly collected seawater samples were used for the determination of inorganic nutrient concentrations, i.e., nitrate and nitrite $\left(\mathrm{NO}_{3}^{-}\right.$and $\left.\mathrm{NO}_{2}^{-}\right)$, ammonia $\left(\mathrm{NH}_{4}^{+}\right)$, phosphate $\left(\mathrm{PO}_{4}^{3-}\right)$, and total alkalinity (TA). Provided are means and standard deviations (in brackets).

\begin{tabular}{|c|c|c|c|c|c|c|c|}
\hline $\begin{array}{l}\text { Site/ } \\
\text { season }\end{array}$ & $\begin{array}{r}\text { Temp } \\
\left({ }^{\circ} \mathrm{C}\right)\end{array}$ & Sal & $\begin{array}{r}\text { Diurnal pH } \\
\text { variation }\end{array}$ & $\begin{array}{r}\mathrm{NO}_{3}^{-} \text {and } \\
\mathrm{NO}_{2}^{-} \\
\left(\mu \mathrm{mol} \mathrm{kg}{ }^{-1}\right)\end{array}$ & $\left.\begin{array}{r}\mathrm{NH}_{4}^{+} \\
(\mu \mathrm{mol} \mathrm{kg} \\
-1\end{array}\right)$ & $\begin{array}{r}\mathrm{PO}_{4}^{3-} \\
\left(\mu \mathrm{mol} \mathrm{kg}{ }^{-1}\right)\end{array}$ & $\begin{array}{r}\text { TA } \\
\left(\mu \mathrm{mol} \mathrm{kg}{ }^{-1}\right)\end{array}$ \\
\hline Avg. winter & $26.07(0.54)$ & $39.18(0.18)$ & $0.11(0.12)$ & $0.32(0.19)$ & $0.38(0.29)$ & $0.08(0.02)$ & $2487(20)$ \\
\hline Avg. summer & $30.85(0.69)$ & $39.44(0.18)$ & $0.05(0.05)$ & $0.61(0.25)$ & $0.54(0.34)$ & $0.04(0.05)$ & 2417 (27) \\
\hline Offshore/winter & $25.97(0.36)$ & $39.18(0.16)$ & $0.04(0.02)$ & $0.4(0.23)$ & $0.38(0.41)$ & $0.09(0.02)$ & $2492(21)$ \\
\hline Offshore/summer & $30.68(0.63)$ & $39.38(0.17)$ & $0.04(0.04)$ & $0.59(0.24)$ & $0.51(0.17)$ & $0.04(0.03)$ & $2439(15)$ \\
\hline Midshore/winter & $26.1(0.49)$ & $39.17(0.2)$ & $0.07(0.04)$ & $0.28(0.22)$ & $0.35(0.19)$ & $0.07(0.02)$ & 2494 (16) \\
\hline Midshore/summer & $30.56(0.61)$ & $39.39(0.14)$ & $0.05(0.05)$ & $0.63(0.26)$ & $0.7(0.53)$ & $0.06(0.08)$ & $2422(26)$ \\
\hline Nearshore/winter & $26.13(0.69)$ & $39.2(0.17)$ & $0.23(0.14)$ & $0.29(0.12)$ & $0.4(0.29)$ & $0.07(0.01)$ & 2476 (19) \\
\hline Nearshore/summer & $31.32(0.59)$ & $39.56(0.15)$ & $0.09(0.06)$ & $0.6(0.28)$ & $0.42(0.16)$ & $0.02(0.01)$ & $2391(15)$ \\
\hline
\end{tabular}

tinuous and exponential nature of bioerosion due to the colonization progress of fouling organisms over time. The significant interaction of reef site and deployment time (Pseudo$\left.F=7.3, p_{\text {PERMANOVA }}<0.001\right)$ shows that only blocks deployed over 12 and 30 months revealed significant site variability; specifically, the differences between nearshore vs. offshore and midshore vs. offshore sites became evident ( $p_{\text {pair-wise }}<0.05$, Table $\mathrm{S} 9$ ). The within-group variability was highest for the nearshore reef, where standard deviations were up to 7 times higher compared to the midshore and offshore reefs.

\subsection{Biotic parameters}

\subsubsection{Benthic community composition}

A detailed account of the benthic community structure of the study sites is provided in Roik et al. (2015). In brief, a low percentage of live substrate $(20 \%)$ and calcifier community cover (hard corals $=11 \%$ and calcifying crusts $=1 \%$ ) was characteristic of the nearshore site, while rock (23\%) and rubble (4\%) were more abundant compared to the other sites. The midshore and offshore reefs provided live benthos cover of around $70 \%$ and a large proportion of calcifiers (48 and $59 \%$ ). The proportion of coral and calcifying crusts, which were dominated by coralline algae, were $38 \%$ and $10 \%$ in the midshore reef compared to $35 \%$ and $23 \%$ in the offshore reef, respectively. Major reef-building coral families were Acroporidae, Pocilloporidae, and Poritidae, forming $32 \%$ $56 \%$ of the total hard coral cover. A soft coral community (of around $25 \%$ ) occupied large areas in the midshore reef. This community was minor in the nearshore and offshore reefs, with $4 \%$ and $8.5 \%$, respectively. Specific benthic accretion rates $G_{\text {benthos }}\left(\mathrm{kg} \mathrm{CaCO}_{3} \mathrm{~m}^{-2} \mathrm{yr}^{-1}\right)$, which were used as input data for the $G_{\text {budget }}$ calculation, were determined using these benthic data in addition to site- and calcifier-specific calcification rates (Tables S2 and S3).

\subsubsection{Epilithic bioeroder/grazer populations along the cross-shelf gradient}

A total of 718 parrotfish and 110 sea urchins were observed and included in subsequent ReefBudget analyses. Parrotfish mean abundances and biomass estimates ranged between $0.08 \pm 0.01$ and $0.17 \pm 0.60$ individuals $\mathrm{m}^{-2}$, and $24.69 \pm 6.04$ and $82.18 \pm 46.67 \mathrm{~g} \mathrm{~m}^{-2}$, respectively (Table S4). The largest parrotfish (category 5 parrotfish, i.e., $>45-70 \mathrm{~cm}$ fork length) were observed at the midshore site. With the exception of the midshore reef, category $1(5-14 \mathrm{~cm})$ parrotfish were commonly observed at all sites. Large parrotfish (category 6 with $>70 \mathrm{~cm}$ fork length) were not observed during the surveys. For sea urchins, mean abundances of $0.002 \pm 0.004$ to 


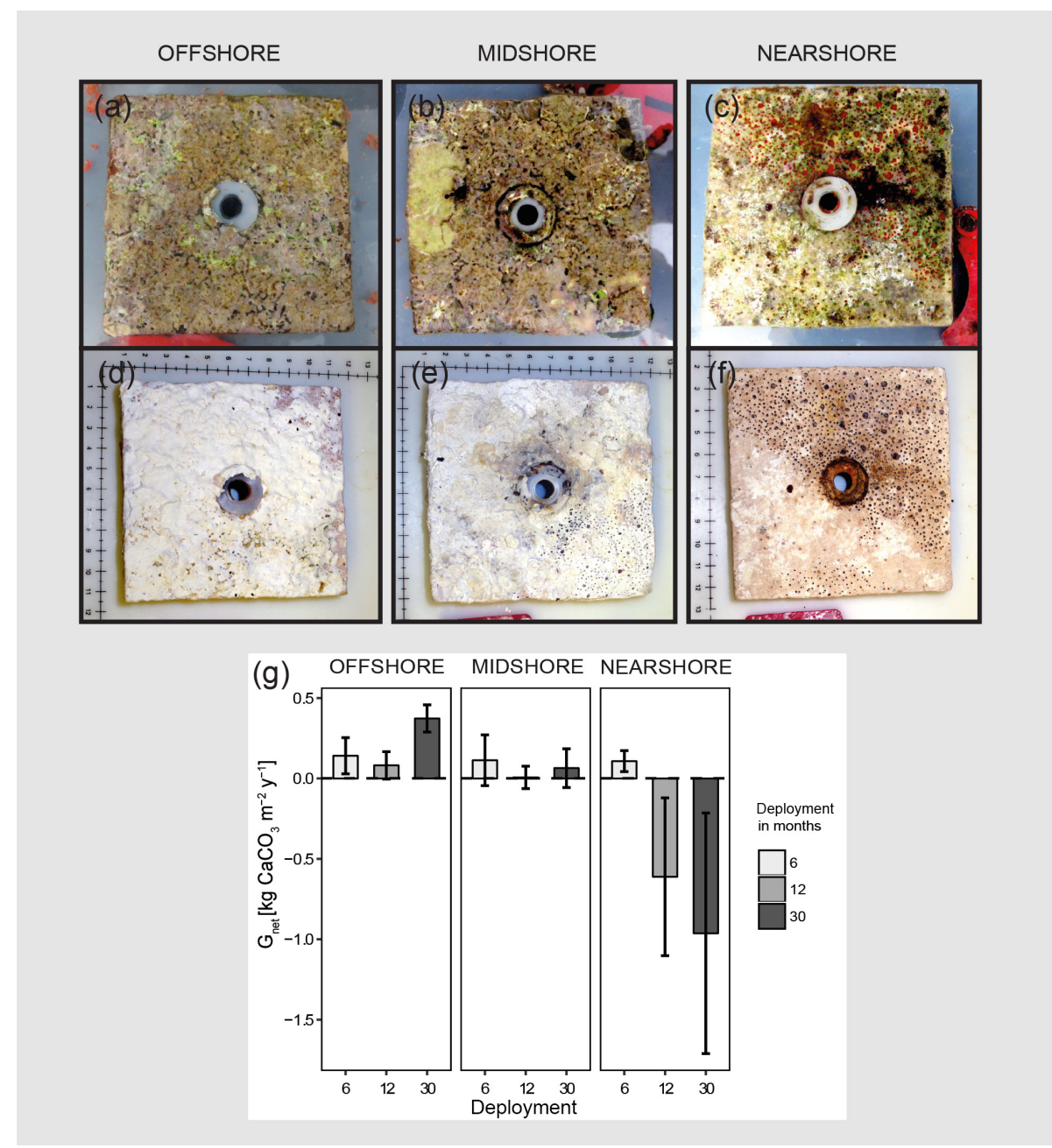

Figure 2. Net-accretion/-erosion rates $\left(G_{\text {net }}\right)$ in the central Red Sea. $G_{\text {net }}$ were measured in situ using limestone blocks $(100 \times 100 \mathrm{~mm})$ that were deployed along the cross-shelf gradient; three sets of four blocks were deployed for 6, 12, or 30 months in each reef site, respectively. Photos (a), (b), and (c) show freshly collected limestone blocks that were recovered after 30 months of deployment. The photos (d), (e), and (f) show the same blocks after bleaching and drying. Boring holes of endolithic sponges are clearly visible in blocks from the nearshore and midshore reef sites. Blocks from the midshore and offshore reefs are covered with crusts of biogenic carbonate mostly accreted by coralline algae assemblages (scales in the photos show centimeters). $G_{\text {net }}$ data obtained from the limestone block assay are plotted in (g). All data are presented as means \pm standard deviations.

$0.014 \pm 0.006$ individuals $\mathrm{m}^{-2}$ per site were observed and mean biomasses of $0.05 \pm 0.04$ to $1.43 \pm 0.98 \mathrm{~g} \mathrm{~m}^{-2}$ estimated per site, respectively (Table S7). The midshore site exhibited the largest range of sea urchin size classes (from categories 1 and 2 to the largest size class 5), while at the other two exposed sites, only the two smallest size classes of sea urchins were recorded.

\subsection{Reef carbonate budgets}

The carbonate budget, $G_{\text {budget }}$, averaged over all sites was $0.66 \pm 2.01 \mathrm{~kg} \mathrm{CaCO} 3 \mathrm{~m}^{-2} \mathrm{yr}^{-1}$, encompassing values ranging from a negative nearshore budget $(-1.48 \pm$ $1.75 \mathrm{~kg} \mathrm{CaCO}_{3} \mathrm{~m}^{-2} \mathrm{yr}^{-1}$ ) to a positive offshore budget $\left(2.44 \pm 1.03 \mathrm{~kg} \mathrm{CaCO}_{3} \mathrm{~m}^{-2} \mathrm{yr}^{-1}\right)$ (Fig. 3 and Table 3). $G_{\text {budget }}$ significantly differed between reef sites ( $F=$ $16.7, p_{\text {ANOVA }}<0.001$, Table S10), where nearshore vs. offshore sites and midshore vs. offshore sites showed significant differences $\left(p_{\text {Tukey HSD }}<0.01\right)$. Further, biotic variables that contribute to the final $G_{\text {budget }}$ were diverse: $G_{\text {benthos }}$ significantly varied between midshore vs. nearshore sites and offshore vs. nearshore sites ( $\left.p_{\text {Tukey HSD }}<0.01\right), G_{\text {netbenthos }}$ varied between all site combinations ( $\left.p_{\text {Tukey HSD }}<0.001\right), E_{\text {echino }}$ significantly differed between midshore and nearshore, and $E_{\text {parrot }}$ variability was similar at all sites. Notably, the within-group variation for the nearshore reef was 5 times higher compared to the midshore reef and the offshore reef. Overall, $15 \%$ of accreted carbon- 


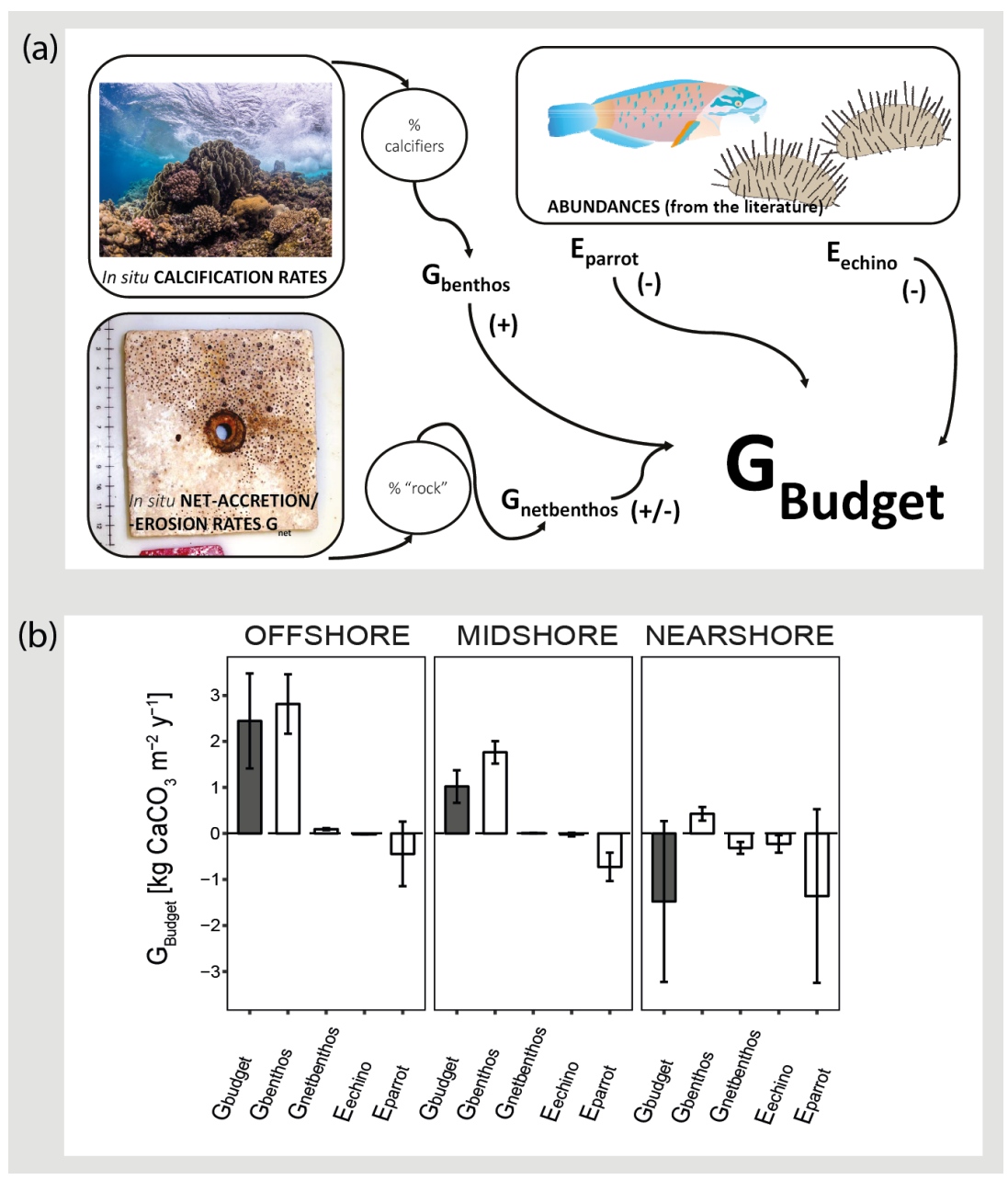

Figure 3. Census-based carbonate budgets in the central Red Sea. A schematic overview of the census-based carbonate budget approach that was adapted from the ReefBudget methodology by Perry et al. (2012) is displayed in (a). Details on input data and equations, employed in the calculations, are available as the Supplement (Text S1 and the respective Supplement Tables). In (b) reef carbonate budgets are plotted in dark grey $\left(G_{\text {budget }}\right)$ and related biotic variables in white. The biotic variables, i.e., site-specific calcification rates of benthic communities $\left(G_{\text {benthos }}\right)$, net-accretion/-erosion rates of reef "rock" surface area $\left(G_{\text {netbenthos }}\right)$, and the epilithic erosion rates of echinoids and parrotfish $\left(E_{\text {echino }}, E_{\text {parrot }}\right)$ contribute to the total reef carbonate budget $\left(G_{\text {budget }}\right)$ at each reef site. All data are presented as means \pm standard deviations. Images from http://www.ian.umces.edu; last access: 1 April2016; photos by Anna Roik.

ate was lost to bioerosion in the offshore reef and $42 \%$ in the midshore reef. The loss even exceeded the accretion by 4-fold in the nearshore reef, i.e., $\sim 440 \%$ proportional loss of accreted carbonate to bioerosion.

\subsection{Abiotic parameters}

\subsubsection{Temperature, salinity, and diurnal $\mathrm{pH}$ variation}

We used abiotic data to characterize environmental conditions at each reef site throughout the year (Tables 4, S11, and S12). Temperature and salinity comprised $\sim 4400$ data points per reef site in the nearshore and offshore reefs, and $\sim 2700$ in the midshore reef; diurnal $\mathrm{pH}$ standard deviations comprised 185 data points for the midshore and offshore sites, and 87 for the nearshore site (Fig. 4). The seasonal mean temperature varied between $26.1 \pm 0.5^{\circ} \mathrm{C}$ in winter and $30.9 \pm 0.7^{\circ} \mathrm{C}$ in summer across all reefs. The cross-shelf difference was largest in summer $\left(\sim 0.6^{\circ} \mathrm{C}\right)$ and significant during both seasons $\left(F=1042.6, p_{\mathrm{ANOVA}}<0.001\right)$. From all sites, the nearshore site experienced the lowest mean temperature $\left(26.1^{\circ} \mathrm{C}\right)$ in winter and the highest $\left(31.3^{\circ} \mathrm{C}\right)$ in summer. In comparison, the midshore and offshore reefs were slightly cooler, with means around $30.6^{\circ} \mathrm{C}$ during summer. Overall salinity was high, ranging between 39.18 and 39.44 over the year. In summer nearshore salinity was significantly increased by 0.36 compared to winter and by 0.18 compared to the other reefs $\left(F=945.3, p_{\mathrm{ANOVA}}<0.001\right)$. Salinity in the midshore and offshore reefs was not significantly different between the two sites. Mean diurnal standard deviations 

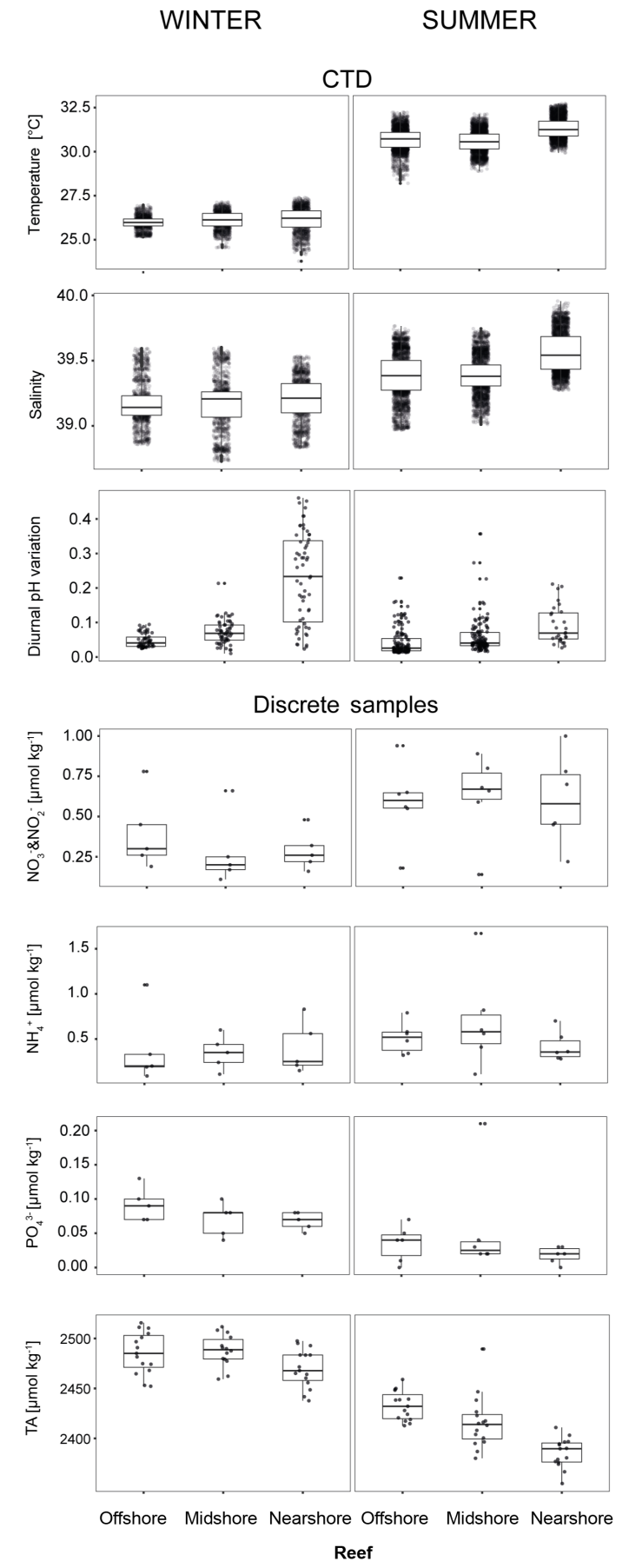

Figure 4. Abiotic conditions in the reef sites. Temperature, salinity, and diurnal $\mathrm{pH}_{\mathrm{NBS}}$ variation (= diurnal standard deviations) were measured continuously over the respective seasons by CTDs (conductivity-temperature-depth loggers including an auxiliary $\mathrm{pH}$ probe). Inorganic nutrients and total alkalinity (TA) were measured in discrete samples across reef sites and seasons. Boxplots illustrate the differences of seawater parameters between the reefs within each season (box: 1st and 3rd quartiles; whiskers: 1.5-fold interquartile range; points: raw data scatter).
Table 5. Coefficients from Spearman rank order correlations for abiotic and biotic predictor variables vs. $G_{\text {net }}$ and $G_{\text {budget }}$. The means of abiotic and biotic variables per reef site were correlated with $G_{\text {net }}$ (=net-accretion/-erosion rates of limestone blocks) and $G_{\text {budget }}$ (= census-based carbonate budgets). Strong and significant correlations ( $\rho$ values $>|0.75|)$ are marked in bold. $P$-values were adjusted by the Benjamini-Hochberg method. CCA: crustose coralline algae; $\mathrm{CC}$ : calcifying crusts

\begin{tabular}{lrr|rr}
\hline & \multicolumn{2}{c|}{$G_{\text {net }}$} & \multicolumn{2}{c}{$G_{\text {budget }}$} \\
\cline { 2 - 6 } Abiotic variables & $\rho$ & $p$ (adj.) & $\rho$ & $p$ (adj.) \\
\hline Temperature & -0.47 & n.s. & -0.52 & n.s. \\
Salinity & $-\mathbf{0 . 8 2}$ & $<0.01$ & $-\mathbf{0 . 8 2}$ & 0.001 \\
Diurnal pH variation & $-\mathbf{0 . 9 5}$ & $<0.001$ & $\mathbf{- 0 . 8 9}$ & $<0.001$ \\
$\mathrm{NO}_{3}^{-}$and $\mathrm{NO}_{2}^{-}$ & $\mathbf{0 . 9 5}$ & $<0.001$ & $\mathbf{0 . 8 9}$ & $<0.001$ \\
$\mathrm{NH}_{4}^{+}$ & 0.47 & n.s. & 0.52 & n.s. \\
$\mathrm{PO}_{4}^{3-}$ & $\mathbf{0 . 8 2}$ & $<0.01$ & $\mathbf{0 . 8 2}$ & 0.001 \\
$\mathrm{TA}^{+}$ & $\mathbf{0 . 9 5}$ & $<0.001$ & $\mathbf{0 . 8 9}$ & $<0.001$ \\
\hline Biotic variables & $\rho$ & $p$ (adj.) & $\rho$ & $p$ (adj.) \\
\hline \% cover CCA/CC & $\mathbf{0 . 9 5}$ & $<0.001$ & $\mathbf{0 . 7 8}$ & $<0.01$ \\
\% cover algae/soft coral/sponge & 0.47 & n.s. & 0.26 & n.s. \\
Parrotfish abundance & $-\mathbf{0 . 9 5}$ & $<0.001$ & -0.49 & n.s. \\
Echinoid abundance & 0.47 & n.s. & -0.54 & n.s. \\
\% cover branching hard corals & & & -0.25 & n.s. \\
\% cover encrusting hard corals & & & 0.26 & n.s. \\
\% cover massive hard corals & & & 0.34 & n.s. \\
\% cover foliose hard corals & & & 0.50 & n.s. \\
\% cover Acroporidae & & & 0.27 & n.s. \\
\% cover Pocilloporidae & & & 0.51 & n.s. \\
\% cover Poritidae & & & 0.45 & n.s. \\
\% cover hard coral & & & 0.63 & n.s. \\
Rugosity & & & $\mathbf{0 . 7 5}$ & $<0.01$ \\
\hline
\end{tabular}

n.s.: not significant.

of $\mathrm{pH}$ ranged between 0.04 and 0.07 of $\mathrm{pH}$ units in the midshore and offshore reefs. The nearshore reef experienced the largest diurnal variations, as indicated by mean diurnal standard deviations of $0.29 \mathrm{pH}$ units during winter and $0.6 \mathrm{pH}$ units during summer. The diurnal $\mathrm{pH}$ fluctuation differed significantly between all reef sites $\left(F=1241, p_{\mathrm{ANOVA}}<0.001\right)$.

\subsubsection{Seawater samples: inorganic nutrients and total alkalinity}

Concentrations of all measured inorganic nutrients were below $1 \mu \mathrm{mol} \mathrm{kg}{ }^{-1}$ (Table 4). $\mathrm{NO}_{3}^{-}$and $\mathrm{NO}_{2}^{-}$were on average between $0.63 \pm 0.26$ and $0.28 \pm 0.22 \mu \mathrm{mol} \mathrm{kg}-1, \mathrm{NH}_{4}^{+}$ between $0.51 \pm 0.17$ and $0.35 \pm 0.19 \mu \mathrm{mol} \mathrm{kg}{ }^{-1}$, and $\mathrm{PO}_{4}^{3-}$ as low as $0.02 \pm 0.01$ and $0.09 \pm 0.02 \mu \mathrm{mol} \mathrm{kg}{ }^{-1}$ (the highest and lowest site-season averages are reported here). By trend, mean $\mathrm{NO}_{3}^{-}$and $\mathrm{NO}_{2}^{-}$and $\mathrm{NH}_{4}^{+}$levels were higher in winter compared to summer, with a difference of 0.29 and $0.16 \mu \mathrm{mol} \mathrm{kg}^{-1}$, respectively (Fig. 4, Tables S11 and $\mathrm{S} 12$ ). In contrast, $\mathrm{PO}_{4}^{3-}$ was significantly higher in winter than in summer, with means differing on average by $0.04 \mu \mathrm{mol} \mathrm{kg}^{-1}\left(F=16, p_{\text {ANOVA }}<0.001\right.$, Table S11). Mean differences across the shelf were $0.1 \mu \mathrm{mol} \mathrm{kg}-1$ in $\mathrm{NO}_{3}^{-}$and $\mathrm{NO}_{2}^{-}$during winter, $0.1 \mu \mathrm{mol} \mathrm{kg}{ }^{-1}$ in $\mathrm{NH}_{4}^{+}$ 
during summer, and $0.02 \mu \mathrm{mol} \mathrm{kg}{ }^{-1}$ in $\mathrm{PO}_{4}^{3-}$ throughout both seasons. TA ranged between $2391 \pm 15$ and $2494 \pm 16 \mu \mathrm{mol} \mathrm{kg}{ }^{-1}$. TA was significantly different between seasons and reef sites (Pseudo- $F_{\text {season }}=297.6$, Pseudo$F_{\text {reefsite }}=22.5, p_{\text {PERMANOVA }}<0.001$, Tables S11 and S12). During both seasons, TA decreased from the offshore to nearshore reefs. During winter, TA was slightly higher, with $2487 \pm 20 \mu \mathrm{mol} \mathrm{kg}^{-1}$ compared to $2417 \pm 27 \mu \mathrm{mol} \mathrm{kg}{ }^{-1}$ during summer. The increase from nearshore to offshore was on average between 20 and $50 \mu \mathrm{mol} \mathrm{kg}^{-1}$ (Fig. 4).

\subsection{Abiotic-biotic correlations}

To explore the relationship between environmental variables and reef growth, we performed correlation analyses. For $G_{\text {net }}$, strong, positive, and significant correlates were calcareous crust cover, $\mathrm{NO}_{3}^{-}$and $\mathrm{NO}_{2}^{-}, \mathrm{PO}_{4}^{3-}$, and TA. Negative correlates were salinity, diurnal $\mathrm{pH}$ variation, and parrotfish abundance (strong correlates: $\rho>|0.75|, p<0.001$ ). For $G_{\text {budget }}$, abiotic correlates were $\mathrm{NO}_{3}^{-}$and $\mathrm{NO}_{2}^{-}, \mathrm{PO}_{4}^{3-}$, and TA, the same correlates as for $G_{\text {net }}$. Looking at significant biotic correlates of $G_{\text {budget }}$, we only found positive relationships, including calcareous crusts, hard corals, and rugosity. Conversely, parrotfish and sea urchin abundances had a negative effect on $G_{\text {budget }}$, but the correlation was weak and not significant $(\rho \sim-0.5)$. The non-calcifying benthos, which represents the coverage by algae, soft corals, and sponges, was not correlated with the dynamics of $G_{\text {budget }}$ and was correlated only weakly and not significantly with $G_{\text {net }}(\rho \sim 0.5)$ (Tables 5, S13, and S14).

\section{Discussion}

Central Red Sea reefs are characterized by unique environmental conditions of high temperature, salinity, TA, and oligotrophy (Fahmy, 2003; Kleypas et al., 1999; Steiner et al., 2014). On a global scale they support remarkable reef growth, sustaining well-established fringing reefs along most of the coastline. To date, processes affecting reef growth in various regions of the Red Sea have mostly been investigated individually. For instance, some studies focused on bioerosion by one specific group of bioeroders only (Alwany et al., 2009; Kleemann, 2001; Mokady et al., 1996), while other studies assessed calcification of reef-building corals (e.g., Cantin et al., 2010; Heiss, 1995; Roik et al., 2015; Sawall et al., 2015). To provide a more comprehensive picture, the present study integrated assessment of the antagonistic processes of calcification and bioerosion. We achieved this in a two-step approach assessing two central metrics of reef growth along a cross-shelf gradient. First, we assessed net-accretion/-erosion rates $\left(G_{\text {net }}\right)$ from three reef sites along the cross-shelf gradient in situ using a limestone block assay. Second, we constructed ecosystem-scale estimates of reef carbonate budgets for Red Sea reef sites
( $G_{\text {budget }}$ ) adapting the census-based ReefBudget approach by Perry et al. (2012). In the following, we highlight the complex dynamics and interactions of reef growth processes and discuss the importance of carbonate budgets as a powerful tool to explore the trajectories of reef growth in a global and historical context.

\subsection{Net-accretion/-erosion rates $\left(G_{\text {net }}\right)$ in the central Red Sea}

\subsubsection{Cross-shelf dynamics in a global context}

The limestone block assay revealed three reef production states in the central Red Sea: (1) net erosion (nearshore), (2) near-neutrality (midshore), and (3) net accretion (offshore). This is in contrast to the pattern observed on the Great Barrier Reef (GBR), where total bioerosion rates were higher in offshore reefs than inshore reefs as assessed from limestone blocks (Tribollet et al., 2002; Tribollet and Golubic, 2005). Generally, most block assay studies conducted in various reef habitats and regions found net-erosive rates. For instance, studies from reefs in the Thai Andaman Sea and Indonesian Java Sea found that the accretion by calcifying crusts, such as coralline algae, were negligible compared to the high degree of bioerosion measured in the limestone blocks (Edinger et al., 2000; Schmidt and Richter, 2013). In contrast, our limestone block assays captured a substantial net accretion rate, in particular for the offshore reef site in the central Red Sea $\left(0.37 \mathrm{~kg} \mathrm{CaCO}_{3} \mathrm{~m}^{-2} \mathrm{yr}^{-1}\right.$ net accretion), indicating that accretion was substantial, while erosion was negligible. The midshore reef was characterized by a nearneutral or minor net accretion $\left(0.06 \mathrm{~kg} \mathrm{CaCO}_{3} \mathrm{~m}^{-2} \mathrm{yr}^{-1}\right)$, on the order of net accretion rates recorded in French Polynesia in reef sites of uninhabited, oceanic atolls (0.08 and $0.62 \mathrm{~kg} \mathrm{CaCO}_{3} \mathrm{~m}^{-2} \mathrm{yr}^{-1}$; Pari et al., 1998). Notably, our study recorded a net-erosive state only in the Red Sea nearshore site $\left(-0.96 \mathrm{~kg} \mathrm{CaCO}_{3} \mathrm{~m}^{-2} \mathrm{yr}^{-1}, 30\right.$ months deployment). This is a moderate rate compared to the larger net erosion observed in the GBR, French Polynesia, and Thailand ( -4 or $-8 \mathrm{~kg} \mathrm{CaCO}_{3} \mathrm{~m}^{-2} \mathrm{yr}^{-1}$ ) (Osorno et al., 2005; Pari et al., 1998; Schmidt and Richter, 2013; Tribollet and Golubic, 2005).

\subsubsection{Limestone block deployment duration and biotic drivers}

Our data show that $G_{\text {net }}$ values were overall higher with longer deployment times, reflecting the succession and early establishment of calcifying crusts and bioeroding communities on the limestone blocks. Due to our sampling design (weight-based block assay), accretion and erosion processes however are simultaneously captured and cannot be disentangled. Overall, the block assay data are indicative of a calcifier-beneficial offshore environment and a nearshore reef habitat that is supporting endolithic bioeroders. 
Following other work, carbonate loss in the 12-month blocks from the nearshore site was supposedly due to a young microbioeroder community, which is typically most active during this early phase. For instance, during the early stages of colonization by endolithic microorganisms, the chlorophyte Ostreobium sp. predominantly contributes to microbioerosion, while the erosion rate steadily increases with deployment time (Grange et al., 2015; Tribollet and Golubic, 2011). Microbioerosion rates have been reported to be $-0.93 \mathrm{~kg} \mathrm{CaCO}_{3} \mathrm{~m}^{-2} \mathrm{yr}^{-1}$ after 12 months of block exposure, which represents the average rate at the early colonization stage when the steadily increasing microbioerosion rate has leveled off (Grange et al., 2015). This rate is slightly higher compared to our measurements of net erosion in the nearshore site after the same deployment time (i.e., $-0.61 \mathrm{~kg}$ $\mathrm{CaCO}_{3} \mathrm{~m}^{-2} \mathrm{yr}^{-1}$ ), and the difference may reflect measurements encompassing both bioerosion and accretion.

Studies have shown that site differences in total bioerosion typically become visible after 1 year of deployment and are significantly enhanced after 3 years (Tribollet and Golubic, 2005). In line with this, the deployment time of 12 months in our study was sufficient to reveal differences between the nearshore and offshore reef sites. Further, calcifying crusts, specifically coralline algae, observed on all blocks from the offshore reef contributed to the respective net accretion. This is corroborated by the positive correlation of their abundances with $G_{\text {net }}$ across all reef sites. Given that we could not identify coral recruits on any limestone block, we assume that contribution of corals to the measured accretion was minor. However, we acknowledge that we might have missed some that could be detected by more sophisticated methods (e.g., microscopic examination).

Significant differences in accretion/erosion between all three sites of the cross-shelf gradient became apparent after 30 months of deployment, and macroborer traces were observed in blocks for the first time (Fig. 2). Over the course of 2-3 years, macrobioeroders such as polychaetes, sipunculids, bivalves, and boring sponges can establish communities in limestone blocks (Hutchings, 1986). Between the first 2 years, macrobioeroder contribution to the total bioerosion can quadruple $\left(0.02-0.09 \mathrm{~kg} \mathrm{CaCO}_{3} \mathrm{~m}^{-2} \mathrm{yr}^{-1}\right)$, before levelling off around 3-4 years of post-deployment (Chazottes et al., 1995).

In our study, the increase in $G_{\text {net }}$ between the 12- and 30month deployment $\left(\sim 0.30 \mathrm{~kg} \mathrm{CaCO}_{3} \mathrm{~m}^{-2} \mathrm{yr}^{-1}\right.$ on average in the nearshore and offshore sites) indicates that calcifying and eroding communities were still in a state of succession. As such, we cannot unequivocally rule out that the blocks deployed for 30 months still represented an immature community, and hence underestimated maximal calcification and erosion rates.

Correlation analyses indicate a significant contribution of parrotfish to the net erosion rates in the nearshore reef. This observation is in line with previous work demonstrating a significant contribution of parrotfish activity to bio- erosion (Alwany et al., 2009; Bellwood, 1995; Bellwood et al., 2003). By comparison, sea urchin size and abundance do not appear to be significant for bioerosion in the central Red Sea reefs. On other reefs, sea urchin bioerosion can be substantial, equaling or even exceeding reef carbonate production (e.g., Bak, 1994). The low contribution of sea urchins to bioerosion on central Red Sea reefs may be a result of potentially low abundances of highly erosive sea urchins (McClanahan and Shafir, 1990). This is in line with the observed parrotfish bite marks and a lack of sea urchins on and in the direct vicinity of the recovered blocks. Taken together, our data confirm that endolithic micro- and macro-bioerosion, as well as parrotfish feeding, likely provide a substantial contribution to calcium carbonate loss.

\subsection{Carbonate budgets $\left(G_{\text {budget }}\right)$ in the central Red Sea}

\subsubsection{Cross-shelf dynamics, regional and global context}

On an ecosystem scale, the $G_{\text {budget }}$ data suggest that the offshore reef site in the central Red Sea loses about $15 \%$ accreted carbonates to bioerosion per year. On the midshore and nearshore reef this loss increases to $42 \%$ and to well over $100 \%$, respectively. By comparison, on the scale of a single coral colony, the boring clam Lithophaga lessepsiana alone can erode up to $40 \%$ of the carbonate deposited by the coral Stylophora pistillata (Lazar and Loya, 1991). In our study sites, the spatial dynamics of the two metrics $G_{\text {net }}$ and the census-based $G_{\text {budget }}$ were consistent and suggest net erosion in nearshore reef sites and net accretion in offshore reef sites in the central Red Sea. Reef growth along the central Red Sea cross-shelf gradient averaged $0.66 \pm 2.01 \mathrm{~kg}$ $\mathrm{CaCO}_{3} \mathrm{~m}^{-2} \mathrm{yr}^{-1}$, which was driven by the substantial positive budget of the offshore reef, reflecting the location and habitat dependence for reef growth potential. That the offshore reef budget is essential to maintain the entire shelf budget has also has been observed on a reef platform in the Maldives. In the respective study, reef accretion was minor and highly heterogeneous at most sites and only a few reef sites at the platform margin promoted substantial net accretion and thereby greatly contributed to the positive average budget of the entire platform (Perry et al., 2017).

The central Red Sea $G_{\text {budget }}$ data presented here are within the range of contemporary reef carbonate budgets from the Atlantic $\left(2.55 \pm 3.83 \mathrm{~kg} \mathrm{CaCO}_{3} \mathrm{~m}^{-2} \mathrm{yr}^{-1}\right)$ and Indian $(1.41 \pm$ $3.02 \mathrm{~kg} \mathrm{CaCO}_{3} \mathrm{~m}^{-2} \mathrm{yr}^{-1}$ ) oceans (Perry et al., 2018). Notably, these data are below the suggested "optimal reef budget" of 5-10 $\mathrm{kg} \mathrm{CaCO}_{3} \mathrm{~m}^{-2} \mathrm{yr}^{-1}$ observed in "healthy", high coral cover fore reefs (see data in Perry et al., 2018, and comparisons therein; Vecsei, 2001, 2004). The overall decline in coral cover is likely central to the reduced carbonate budgets in contemporary reefs. For instance, the reefs investigated in the present study do not exceed a coral cover of $40 \%$ (as observed in the offshore study site). In comparison, the dataset compiled by Vecsei (2001) encompasses reef sites with hard 
coral cover of up to $80 \%$ for the Indo-Pacific and up to $95 \%$ on various Pacific islands. Further, the reduced contemporary carbonate budgets coincide with the observed decrease in calcification rates of Red Sea corals at large (Cantin et al., 2010; Steiner et al., 2018). As such, the effect of climate change and the corresponding increase in seawater temperature may have severe consequences via overall decrease in coral reef cover as well as via reduced calcification of the resident corals. Hence, although the present $G_{\text {budget }}$ data still suggest effective barrier reef formation in the central Red Sea (substantial accretion on the offshore reef), carbonate accretion rates and therefore reef formation in the central Red Sea may be hampered in the long run by the ongoing warming trend.

\subsubsection{Biotic drivers}

\section{Regional differences}

Cross-shelf patterns of $G_{\text {budget }}$ drivers from the central Red Sea are distinct from other reef systems. The central Red Sea system is characterized by a nearshore site with a negative $G_{\text {budget }}$, impacted by high parrotfish abundances and erosion rates, low coral cover, and putatively considerable endolithic bioerosion rates (see the discussion of $G_{\text {net }}$ data). Conversely, the offshore reef is characterized by high calcification rates, driven by high coral and coralline algae abundances. In the GBR an opposing trend with high net accretion in the nearshore reefs (Browne et al., 2013) coincided with high coral cover, low bioerosion rates, and the lowest rates of parrotfish bioerosion (Hoey and Bellwood, 2007; Tribollet et al., 2002). On Caribbean reefs, parrotfish erosion rates were higher on leeward reefs (which may be similar to protected nearshore habitats), but in contrast to the central Red Sea, these sites were typically characterized by overall high coral cover driving a positive $G_{\text {budget }}$ (Perry et al., 2012, 2014). This inter-regional comparison strongly suggests that reef accretion/erosion dynamics encountered in any given reef system cannot be readily extrapolated to other reef systems. Hence, in situ assessments of individual reef systems are required to unravel local dynamics and responses to environmental change, and are therefore imperative for the development of effective management measures.

\section{The role of coral and coralline crusts}

Benthic calcifiers, in particular reef-building corals, are major contributors to carbonate production and are considered the most influential drivers of $G_{\text {budgets }}$ globally (Franco et al., 2016). Corals can contribute as much as $90 \%$ to the gross carbonate production across different reef zones, which also includes low coral cover lagoonal and rubble habitats (Perry et al., 2017). Hence, loss of coral cover rapidly gives way to increased bioerosion and thereby critically contributes to reef framework degradation (Perry and Morgan, 2017). Indeed, on Caribbean reefs, $G_{\text {budget }}$ data were reported to shift into erosional states once live hard coral cover was below $10 \%$ (Perry et al., 2013). A live coral cover threshold remains to be determined for the central Red Sea and will require evaluation of a larger dataset. However, we find that the nearshore reef featuring a negative $G_{\text {budget }}$ is characterized by a coral cover of $11 \%$, while the midshore and offshore reefs, characterized by near-neutral vs. positive carbonate budgets, both feature similar average coral covers (at $35 \%$ and $40 \%$, respectively). In this respect, our data show that a 2 -fold higher abundance of coralline algae and other encrusting calcifiers in the offshore reef (compared to the midshore reef) significantly added to a higher $G_{\text {budget }}$. The positive contribution of coralline algae for central Red Sea reef accretion is corroborated by their strong and significant correlation to $G_{\text {budget }}$. Coralline algae in particular are considered an important contributor to reef growth, as they stabilize the reef framework through "cementation" (Perry et al., 2008) and by habitat priming for successful coral recruitment (Heyward and Negri, 1999).

\section{Epilithic grazers}

Epilithic grazers such as parrotfish and sea urchin are considered important drivers of bioerosion on many reefs (Hoey and Bellwood, 2007; Mokady et al., 1996; Pari et al., 1998; Reaka-Kudla et al., 1996). Sea urchins were identified as significant bioeroders in some reefs of Réunion Island, French Polynesia, and in the GoA, northern Red Sea (Chazottes et al., 1995, 2002; Mokady et al., 1996). For the northern Red Sea, sea urchins were abundant, and their removal of reef carbonates was estimated to range around $13 \%-22 \%$ of total reef slope calcification (Mokady et al., 1996). In contrast, sea urchins were rare in our study sites, contributing only $2 \%-3 \%$ of the total bioerosion, resulting in low contributions to $G_{\text {budget }}$. Only in the net-erosive nearshore reef were sea urchins more abundant, causing $12 \%$ of total bioerosion.

Compared to sea urchins, parrotfish played a more important role for $G_{\text {budgets }}$ throughout the entire reef system, contributing $70 \%-96 \%$ of the total bioerosion. In the correlation analyses, both grazers, i.e., sea urchins and parrotfish, negatively correlated with $G_{\text {budget }}$; however, these correlations were not very strong $(\rho \sim-0.5)$ and non-significant. The weak correlation may be influenced by a considerable variability in the reef census dataset, specifically regarding parrotfish abundances. Observer bias (parrotfish keep minimum distance from surveyors during dives and may therefore not enter survey plots; Claudia Pogoreutz, personal observation, 2014), natural (e.g., species distribution, habitat preferences, reef rugosity, and mobility or large roving excavating species, such as Bolbometopon muricatum), and/or anthropogenically driven factors (e.g., differential fishing pressure) may also contribute to the observed data heterogeneity (McClanahan, 1994; McClanahan et al., 1994). Indeed, the Saudi Arabian central Red Sea has been subject to decade long fish- 
ing pressure, which has significantly altered reef fish community structures and reduced overall fish biomass compared to less impacted Red Sea regions (Kattan et al., 2017). Unregulated fishing could at least in part explain the differences of fish abundance dynamics between the present study and reefs on the GBR and the Caribbean. The heterogeneity of grazer populations further propagates into $G_{\text {budget }}$ estimates, resulting in a considerable within-site variability that reduces the power of statistical tests and correlations.

\subsection{Abiotic factors and reef growth dynamics}

Reef habitats in the central Red Sea are characterized by abiotic factors that differ from the majority of tropical reef environments (Couce et al., 2012; Kleypas et al., 1999). Our sites were exposed to high summer temperatures $\left(30-33^{\circ} \mathrm{C}\right)$ and a high salinity throughout the year (39-40). Inorganic nutrients were mostly far below $1 \mu \mathrm{mol} \mathrm{kg}{ }^{-1}$, whereas TA was comparably high, $2400-2500 \mu \mathrm{mol} \mathrm{kg}{ }^{-1}$, values typical for much of the Red Sea basin (Acker et al., 2008; Steiner et al., 2014). As such, the Red Sea is considered a natural model system or "laboratory", which can advance our understanding of ecosystem functioning under extreme or marginal conditions, of which some are projected under ocean change scenarios (Camp et al., 2018). The study of such natural systems is a challenge and the documentation of governing factors both abiotic and biotic will contribute to a better understanding of the dynamics and interactions, which can significantly improve ecosystem-scale predictions (Boyd and Hutchins, 2012; Boyd and Brown, 2015; Camp et al., 2018). In the present study, reef framework decline (i.e., net erosion) was associated with reef habitats of slightly increased salinity and stronger diel $\mathrm{pH}$ fluctuations, which are characteristic of shallow water, limited flow systems, and semi-enclosed reefs (Camp et al., 2017; Shamberger et al., 2017), such as the nearshore study site investigated here (Roik et al., 2016). On the other hand, positive reef growth was associated with reef habitats characterized by higher TA levels, but also with slightly increased inorganic nutrient species, namely $\mathrm{NO}^{3-}$ and $\mathrm{NO}^{2-}$ and $\mathrm{PO}_{4}^{3-}$.

\subsubsection{The nearshore site}

The nearshore reef is located on the shelf, surrounded by shallow waters of extended residency time, and has a lower water exchange rate compared to the other two reef sites (Roik et al., 2016). Evaporation and limited flow, particularly during summer, may increase salinity, which was overall higher at this reef site. However, the difference to the other sites was minuscule and unlikely to have affected calcifying (Röthig et al., 2016) and bioeroding biota. The variability of diurnal $\mathrm{pH}$ on the other hand presumably has stronger impacts on the performance of calcifiers and bioeroders. Previously, $\mathrm{pH}$ variability across a reef flat and slope was demonstrated to correlate with net accretion dynamics by showing higher net accretion prevailing in sites of less variable $\mathrm{pH}$ conditions (Price et al., 2012; Silbiger et al., 2014), which reflects the pattern observed here.

The fluctuation in $\mathrm{pH}$ may (in part) represent a biotic feedback signature in reef habitats, which entails changes in seawater chemistry caused by dominant biotic processes, i.e., calcification, carbonate dissolution, and respiration/photosynthesis (Bates et al., 2010; Silverman et al., 2007a; Zundelevich et al., 2007). Commonly, such pH fluctuations are influenced by changes in carbonate system variables, e.g., DIC and TA (Shaw et al., 2012; Silbiger et al., 2014), which can modify the antagonistic processes of calcification and bioerosion/dissolution (e.g., Andersson, 2015; Langdon et al., 2000; Tribollet et al., 2009). In particular, in our nearshore study site, where benthic macro-community abundance was low, biological activity in the sandy bottom (e.g., permeable carbonate sands) might be a crucial factor contributing to the biotic feedback (Andersson, 2015; $\mathrm{Cy}-$ ronak et al., 2013; Eyre et al., 2018).

\subsubsection{Total alkalinity and nutrients}

An increase in TA is often associated with increased carbonate ion concentration and $\Omega_{\mathrm{a}}$, which facilitate the precipitation of carbonates supporting the performance of reef builders (Albright et al., 2016, 2018; Langdon et al., 2000; Schneider and Erez, 2006; Silbiger et al., 2014). We identified a positive correlation of TA with reef growth in our dataset. The difference in TA across our study sites was small, but in the range of natural cross-shelf differences reported from other reefs (e.g., reefs in Bermuda, $20-40 \mu \mathrm{mol} \mathrm{kg}-1$, Bates et al., 2010), and as high as $50 \mu \mathrm{mol} \mathrm{kg}{ }^{-1}$, which was shown to enhance community net calcification in a reef-enclosed lagoon (Albright et al., 2016). On the other hand, high calcification rates can deplete TA, whereas dissolution of carbonates can enrich TA measurably, specifically in (semi-)enclosed systems (Bates et al., 2010), which we did not observe along the cross-shelf gradient. It remains to be further investigated how TA dynamics across the shelf relate to reef growth processes.

Although increased nutrients are commonly linked to reef degradation initiated through phase shifts, increased bioerosion rates, and/or the decline of calcifiers (Fabricius, 2011; Grand and Fabricius, 2010; Holmes, 2000), our dataset suggests that a highly oligotrophic system such as the central Red Sea reefs may benefit from slight increases in certain nutrient species. Specifically, natural minor increases in $\mathrm{N}$ and $\mathrm{P}$ might have a positive effect on ecosystem productivity and functioning, including carbonate budgets. A moderate natural source of nutrients, e.g., from sea bird populations, can indeed have a positive effect on ecosystem functioning (Graham et al., 2018). Interestingly, our study also identified $\mathrm{PO}_{4}^{3-}$ concentration as an abiotic correlate of reef growth. In the Red Sea, high N:P ratios indicate that $\mathrm{P}$ is a limiting micronutrient, e.g., for phytoplankton (Fahmy, 2003). $\mathrm{PO}_{4}^{3-}$ 
is not only essential for pelagic primary producers, but also for reef calcifiers and their photosymbionts, such as the stony corals and their micro-algal Symbiodiniaceae endosymbionts (Ferrier-Pagès et al., 2016; LaJeunesse et al., 2018). Experimental studies have demonstrated that $\mathrm{PO}_{4}^{3-}$ provision can maintain the coral-algae symbiosis in reef-building corals under heat stress (Ezzat et al., 2016). Conversely, P limitation can increase the stress susceptibility of this symbiosis (Pogoreutz et al., 2017; Rädecker et al., 2015; Wiedenmann et al., 2013). In light of our results, it will be of interest to link spatio-temporal variation of inorganic nutrient ratios with patterns of reef resilience in the central Red Sea to understand their effects on long-term trends of reef growth.

\subsection{Reef growth trajectories in the Red Sea}

Carbonate budgets provide insight into ecosystem functioning and can be used as a powerful tool to track reef trajectories through time. This includes the exploration of past and current reef trends, which may be critical for prediction of future reef development (Januchowski-Hartley et al., 2017). Indeed, the absence of comparative baseline data limits a historical perspective on the central Red Sea $G_{\text {budget }}$ presented here. Previously reported Red Sea data include pelagic and reefal carbonate accretion rates from 1998, estimated using basin-scale historical measurements of TA (Steiner et al., 2014). Another dataset employed the censusbased budget approach for a seasonal high-latitude fringing reef in the GoA from 1994 to 1996 (Dullo et al., 1996), which is methodologically similar to the ReefBudget approach. Both reef growth estimates provide similar rates: the TA-based reef accretion estimate from 1998 was $0.9 \mathrm{~kg} \mathrm{CaCO}_{3} \mathrm{~m}^{-2} \mathrm{yr}^{-1}$ and the GoA fringing reef budget from 1994 to 1996 ranged between 0.7 and $0.9 \mathrm{~kg}$ $\mathrm{CaCO}_{3} \mathrm{~m}^{-2} \mathrm{yr}^{-1}$. Additionally, our gross calcification rate of the offshore benthic communities ( $\left.G_{\text {benthos }}\right)$ compares well with the maxima measured in the GoA reefs in 1994 (i.e., $2.7 \mathrm{~kg} \mathrm{CaCO}_{3} \mathrm{~m}^{-2} \mathrm{yr}^{-1}$ ) (Heiss, 1995). The $G_{\text {budgets }}$ assessed in the present study are in accordance with these data, indicating stable reef growth rates in the Red Sea basin in the last 20 years, despite the ongoing warming trend and observed impairment of calcification in a Red Sea coral species (Cantin et al., 2010; Raitsos et al., 2011). However, data are limited and comparisons between the central Red Sea and the GoA should be interpreted with caution. Due to the strong latitudinal gradient of temperature and salinity in addition to differences in seasonality between the central Red Sea and the GoA, reef growth dynamics from the two regions may fundamentally differ. Hence, far larger (and ideally crosslatitude) datasets will be needed to determine more accurately whether a declining calcification capacity of Red Sea corals has already become a basin-scale phenomenon and whether there are coral species-specific differences. In this study we have demonstrated that offshore reefs in the central Red Sea still maintain a positive carbonate budget yet can be considered "underperforming" and below "optimal reefal production" (Vecsei, 2004). In the context of reef growth trajectories, the data presented in this study should serve as a valuable contemporary baseline for comparative future studies in the central Red Sea. Importantly, these data were collected before the Third Global Bleaching Event, which impacted the region during the summers of 2015 and 2016 (Monroe et al., 2018). The present effort therefore will be of great value when assessing potential (long-term) changes in Red Sea $G_{\text {budgets }}$ following this substantial disturbance.

\section{Conclusions}

The Red Sea is a geographic region where coral reefs exist in a naturally high-temperature and high-salinity environment. Baseline data for reef growth from this region are scarce and particularly valuable as they provide insight into reef functioning under environmental conditions that deviate from the global average for coral reefs. As such, they can provide a potential outlook to future ocean scenarios. Overall, we found net-erosion in a nearshore reef site, about netneutral growth in a midshore reef site, and net-accretion in an offshore reef site. A comparison of central Red Sea reef growth dynamics to other major reef systems revealed important differences and underlines the necessity for in situ studies in underexplored major reef regions. For instance, our study highlights the importance of coralline algae as a reefbuilding agent and shows that the erosive forces in the Red Sea are not as pronounced (yet) as observed elsewhere. Reef growth on Red Sea offshore reefs is comparable to the majority of reef growth estimates from other geographic regions, which today perform well below what has been considered a "healthy reef" carbonate budget. A first comparison with data from recent years suggests that reef growth rates in the central Red Sea have not decreased substantially over the last two decades, despite potential negative effects of the ongoing warming trend. The absence of comparative long-term data from the region hampers long-term predictions. We therefore advocate additional research to better inform future trajectories of reef growth dynamics under consideration of the challenging and unique environmental settings of the Red Sea.

Data availability. All data are provided in the paper and the Supplement. In addition, physicochemical datasets, reef census, and limestone block assay raw data are available from the Dryad Digital Repository (https://doi.org/10.5061/dryad.19kd421; Roik et al., 2018).

Supplement. The supplement related to this article is available online at: https://doi.org/10.5194/bg-15-6277-2018-supplement. 
Author contributions. Resources: CRV; project administration: CRV; conceptualization: AR; investigation: AR, TR, CP; methodology: AR, TR, CP; formal analysis: AR, CP, VS; validation: AR, CP, TR, VS, CRV; visualization: AR; funding acquisition: CRV; writing - original draft: AR; writing - review and editing: CRV, TR, CP, VS, AR; data curation: AR.

Competing interests. The authors declare that they have no conflict of interest.

Acknowledgements. We thank the Coastal and Marine Resources Lab (CMOR) at King Abdullah University of Science and Technology (KAUST) for logistics and operations at sea (Esam AlJahdali, Abdullah Al-Jahdali, Ghazi Al-Jahdali, Ramzi Al-Jahdali, Haitham Al-Jahdali, Francis Mallon, Paul Müller, and David Pallett), as well as for the assistance with the deployment of oceanographic instruments (Lloyd Smith, Mark D. Pantalita, and Samer Mahmoud). We would like to acknowledge field assistance by Cornelia Roder and Christoph Walcher in setting up the reef monitoring sites. We thank Maha Khalil for providing a map of the study sites. We are grateful for the comments and suggestions from two anonymous reviewers and Steeve Comeau (Laboratoire d'Océanographie de Villefranche) for his critical comments and helpful suggestions to improve the manuscript. Research reported in this publication was supported by funding to Christian R. Voolstra from KAUST.

Edited by: Jean-Pierre Gattuso

Reviewed by: Steeve Comeau and two anonymous referees

\section{References}

Acker, J., Leptoukh, G., Shen, S., Zhu, T., and Kempler, S.: Remotely-sensed chlorophyll a observations of the northern Red Sea indicate seasonal variability and influence of coastal reefs, J. Marine Syst., 69, 191-204, https://doi.org/10.1016/j.jmarsys.2005.12.006, 2008.

Albright, R., Caldeira, L., Hosfelt, J., Kwiatkowski, L., Maclaren, J. K., Mason, B. M., Nebuchina, Y., Ninokawa, A., Pongratz, J., Ricke, K. L., Rivlin, T., Schneider, K., Sesboüé, M., Shamberger, K., Silverman, J., Wolfe, K., Zhu, K., and Caldeira, K.: Reversal of ocean acidification enhances net coral reef calcification, Nature, 531, 362-365, https://doi.org/10.1038/nature17155, 2016.

Albright, R., Takeshita, Y., Koweek, D. A., Ninokawa, A., Wolfe, K., Rivlin, T., Nebuchina, Y., Young, J., and Caldeira, K.: Carbon dioxide addition to coral reef waters suppresses net community calcification, Nature, 555, 516-519, https://doi.org/10.1038/nature25968, 2018.

Alwany, M. A., Thaler, E., and Stachowitsch, M.: Parrotfish bioerosion on Egyptian Red Sea reefs, J. Exp. Mar. Biol. Ecol., 371, 170-176, https://doi.org/10.1016/j.jembe.2009.01.019, 2009.

Anderson, M. J., Gorley, R. N., and Clarke, K. R.: PERMANOVA+ for PRIMER: Guide to software and statistical methods, PRIMER-E Ltd, Plymouth, United Kingdom, 2008.

Andersson, A. J.: A Fundamental Paradigm for Coral Reef Carbonate Sediment Dissolution, Front. Mar. Sci., 2, 52, 1-8, 2015.
Bak, R. P. M.: Sea urchin bioerosion on coral reefs: place in the carbonate budget and relevant variables, Coral Reefs, 13, 99-103, https://doi.org/10.1007/BF00300768, 1994.

Bak, R. P. M., Nieuwland, G., and Meesters, E. H.: Coral Growth Rates Revisited after 31 Years: What is Causing Lower Extension Rates in Acropora Palmata?, Bull. Mar. Sci., 84, 287-294, 2009.

Bannerot, S. P. and Bohnsack, J. A.: A stationary visual census technique for quantitatively assessing community structure of coral reef fishes, NOAA, available from: http://core.kmi.open.ac. uk/download/pdf/11018492.pdf (last access: 1 September 2014), 1986.

Bates, N. R., Amat, A., and Andersson, A. J.: Feedbacks and responses of coral calcification on the Bermuda reef system to seasonal changes in biological processes and ocean acidification, Biogeosciences, 7, 2509-2530, https://doi.org/10.5194/bg7-2509-2010, 2010.

Bellwood, D. R.: Direct estimate of bioerosion by two parrotfish species, Chlorurus gibbus and C. sordidus, on the Great Barrier Reef, Australia, Mar. Biol., 121, 419-429, https://doi.org/10.1007/BF00349451, 1995.

Bellwood, D. R., Hoey, A. S., and Choat, J. H.: Limited functional redundancy in high diversity systems: resilience and ecosystem function on coral reefs, Ecol. Lett., 6, 281-285, 2003.

Boyd, P. and Hutchins, D.: Understanding the responses of ocean biota to a complex matrix of cumulative anthropogenic change, Mar. Ecol. Prog. Ser., 470, 125-135, https://doi.org/10.3354/meps10121, 2012.

Boyd, P. W. and Brown, C. J.: Modes of interactions between environmental drivers and marine biota, Front. Mar. Sci., 9, 1-7, https://doi.org/10.3389/fmars.2015.00009, 2015.

Browne, N. K., Smithers, S. G., and Perry, C. T.: Carbonate and terrigenous sediment budgets for two inshore turbid reefs on the central Great Barrier Reef, Mar. Geol., 346, 101-123, https://doi.org/10.1016/j.margeo.2013.08.011, 2013.

Bruggemann, J., van Kessel, A., van Rooij, J., and Breeman, A.: Bioerosion and sediment ingestion by the Caribbean parrotfish Scarus vetula and Sparisoma viride: implications of fish size, feeding mode and habitat use, Mar. Ecol. Prog. Ser., 134, 59-71, https://doi.org/10.3354/meps134059, 1996.

Buddemeier, R. W.: Symbiosis: Making light work of adaptation, Nature, 388, 229-230, https://doi.org/10.1038/40755, 1997.

Cai, W.-J., Ma, Y., Hopkinson, B. M., Grottoli, A. G., Warner, M. E., Ding, Q., Hu, X., Yuan, X., Schoepf, V., Xu, H., Han, C., Melman, T. F., Hoadley, K. D., Pettay, D. T., Matsui, Y., Baumann, J. H., Levas, S., Ying, Y., and Wang, Y.: Microelectrode characterization of coral daytime interior $\mathrm{pH}$ and carbonate chemistry, Nat. Commun., 7, 11144, https://doi.org/10.1038/ncomms11144, 2016.

Camp, E. F., Nitschke, M. R., Rodolfo-Metalpa, R., Houlbreque, F., Gardner, S. G., Smith, D. J., Zampighi, M., and Suggett, D. J.: Reef-building corals thrive within hotacidified and deoxygenated waters, Sci. Rep., 7, 2434, https://doi.org/10.1038/s41598-017-02383-y, 2017.

Camp, E. F., Schoepf, V., Mumby, P. J., Hardtke, L. A., RodolfoMetalpa, R., Smith, D. J., and Suggett, D. J.: The Future of Coral Reefs Subject to Rapid Climate Change: Lessons from Natural Extreme Environments, Front. Mar. Sci., 4, 1-21, https://doi.org/10.3389/fmars.2018.00004, 2018. 
Cantin, N. E., Cohen, A. L., Karnauskas, K. B., Tarrant, A. M., and McCorkle, D. C.: Ocean Warming Slows Coral Growth in the Central Red Sea, Science, 329, 322-325, https://doi.org/10.1126/science.1190182, 2010.

Carricart-Ganivet, J. P., Cabanillas-Terán, N., Cruz-Ortega, I., and Blanchon, P.: Sensitivity of Calcification to Thermal Stress Varies among Genera of Massive Reef-Building Corals, PLoS ONE, 7, e32859, https://doi.org/10.1371/journal.pone.0032859, 2012.

Chazottes, V., Campion-Alsumard, T. L., and Peyrot-Clausade, M.: Bioerosion rates on coral reefs: interactions between macroborers, microborers and grazers (Moorea, French Polynesia), Palaeogeogr. Palaeocl., 113, 189-198, https://doi.org/10.1016/0031-0182 (95)00043-L, 1995.

Chazottes, V., Le Campion-Alsumard, T., Peyrot-Clausade, M., and Cuet, P.: The effects of eutrophication-related alterations to coral reef communities on agents and rates of bioerosion (Reunion Island, Indian Ocean), Coral Reefs, 21, 375-390, 2002.

Cohen, A. L. and Holcomb, M.: Why corals care about ocean acidification: uncovering the mechanism, Oceanography, 22, 118127, 2009.

Cooper, T. F., Death, G., Fabricius, K. E., and Lough, J. M.: Declining coral calcification in massive Porites in two nearshore regions of the northern Great Barrier Reef, Glob. Change Biol., 14, 529-538, https://doi.org/10.1111/j.1365-2486.2007.01520.x, 2008.

Couce, E., Ridgwell, A., and Hendy, E. J.: Environmental controls on the global distribution of shallow-water coral reefs, J. Biogeogr., 39, 1508-1523, https://doi.org/10.1111/j.13652699.2012.02706.x, 2012.

Cyronak, T., Santos, I. R., McMahon, A., and Eyre, B. D.: Carbon cycling hysteresis in permeable carbonate sands over a diel cycle: Implications for ocean acidification, Limnol. Oceanogr., 58, 131-143, https://doi.org/10.4319/lo.2013.58.1.0131, 2013.

Death, G., Lough, J. M., and Fabricius, K. E.: Declining Coral Calcification on the Great Barrier Reef, Science, 323, 116-119, https://doi.org/10.1126/science.1165283, 2009.

Dullo, P. D. W.-C., Gektidis, D. M., Golubic, P. D. S., Heiss, D. G. A., Kampmann, D. B. H., Kiene, D. W., Kroll, D. Ö. D. K., Kuhrau, D. B. M. L., Radtke, D. G., Reijmer, D. J. G., Reinicke, D. G. B., Schlichter, P. D. D., Schuhmacher, P. D. H., and Vogel, K.: Factors controlling holocene reef growth: An interdisciplinary approach, Facies, 32, 145-188, https://doi.org/10.1007/BF02536867, 1995.

Dullo, W.-C., Reijmer, J., Schuhmacher, H., Eisenhauer, A., Hassan, M., and Heiss, G.: Holocene reef growth and recent carbonate production in the Red Sea, available from: https:// www.researchgate.net/publication/230751439_Holocene_reef_ growth_and_recent_carbonate_production_in_the_Red_Sea (last access: 27 April 2016), 1996.

Eakin, C. M.: A tale of two Enso Events: carbonate budgets and the influence of two warming disturbances and intervening variability, Uva Island, Panama, Bull. Mar. Sci., 69, 171-186, 2001.

Edinger, E. N., Limmon, G. V., Jompa, J., Widjatmoko, W., Heikoop, J. M., and Risk, M. J.: Normal coral growth rates on dying reefs: Are coral growth rates good indicators of reef health?, Mar. Pollut. Bull., 40, 404-425, 2000.

Enochs, I. C.: Ocean acidification enhances the bioerosion of a common coral reef sponge: implications for the persis- tence of the Florida Reef Tract, Bull. Mar. Sci., 91, 271-290, https://doi.org/10.5343/bms.2014.1045, 2015.

Eyre, B. D., Cyronak, T., Drupp, P., Carlo, E. H. D., Sachs, J. P., and Andersson, A. J.: Coral reefs will transition to net dissolving before end of century, Science, 359, 908-911, https://doi.org/10.1126/science.aao1118, 2018.

Ezzat, L., Maguer, J.-F., Grover, R., and Ferrier-Pagès, C.: Limited phosphorus availability is the Achilles heel of tropical reef corals in a warming ocean, Sci. Rep., 6, 31768, https://doi.org/10.1038/srep31768, 2016.

Fabricius, K. E.: Factors Determining the Resilience of Coral Reefs to Eutrophication: A Review and Conceptual Model, in: Coral Reefs: An Ecosystem in Transition, edited by: Dubinsky, Z. and Stambler, N., Springer Netherlands, Dordrecht, 493-505, available from: http://www.springerlink.com/index/10 1007/978-94-007-0114-4_28 (last access: 8 May 2012), 2011.

Fahmy, M.: Water quality in the Red Sea coastal waters (Egypt): Analysis of spatial and temporal variability, Chem. Ecol., 19, 6777, https://doi.org/10.1080/0275754031000087074, 2003.

Fang, J. K. H., Mello-Athayde, M. A., Schönberg, C. H. L., Kline, D. I., Hoegh-Guldberg, O., and Dove, S.: Sponge biomass and bioerosion rates increase under ocean warming and acidification, Glob. Change Biol., 19, 3581-3591, https://doi.org/10.1111/gcb.12334, 2013.

Ferrier-Pagès, C., Godinot, C., D'Angelo, C., Wiedenmann, J., and Grover, R.: Phosphorus metabolism of reef organisms with algal symbionts, Ecol. Monogr., 86, 262-277, https://doi.org/10.1002/ecm.1217, 2016.

Franco, C., Hepburn, L. A., Smith, D. J., Nimrod, S., and Tucker, A.: A Bayesian Belief Network to assess rate of changes in coral reef ecosystems, Environ. Model. Softw., 80, 132-142, https://doi.org/10.1016/j.envsoft.2016.02.029, 2016.

Glynn, P. W.: Bioerosion and coral-reef growth: a dynamic balance, in: Life and Death of Coral Reefs, edited by: Birkeland, C., Chapman and Hall, Ney York, USA, 68-94, 1997.

Glynn, P. W. and Manzello, D. P.: Bioerosion and Coral Reef Growth: A Dynamic Balance, in: Coral Reefs in the Anthropocene, edited by: Birkeland, C., Springer Netherlands, 67-97, 2015.

Graham, N. A. J., Wilson, S. K., Carr, P., Hoey, A. S., Jennings, S., and MacNeil, M. A.: Seabirds enhance coral reef productivity and functioning in the absence of invasive rats, Nature, 559, 250 253, https://doi.org/10.1038/s41586-018-0202-3, 2018.

Grand, H. M. L. and Fabricius, K. E.: Relationship of internal macrobioeroder densities in living massive Porites to turbidity and chlorophyll on the Australian Great Barrier Reef, Coral Reefs, 30, 97-107, https://doi.org/10.1007/s00338-010-0670-x, 2010.

Grange, J. S., Rybarczyk, H., and Tribollet, A.: The three steps of the carbonate biogenic dissolution process by microborers in coral reefs (New Caledonia), Environ. Sci. Pollut. Res., 22, 13625-13637, https://doi.org/10.1007/s11356-014-4069-z, 2015.

Green, A. L. and Bellwood, D. R.: Monitoring functional groups of herbivorous reef fishes as indicators of coral reef resilience: a practical guide for coral reef managers in the Asia Pacific region, International Union for Conservation of Nature, IUCN, Gland, Switzerland, available from: ftp://ftp.library.noaa.gov/noaa documents.lib/CoRIS/IUCN_herbivorous_reef-fishes_2009.pdf (last access: 30 September 2017), 2009. 
Heiss, G. A.: Carbonate production by scleractinian corals at Aqaba, Gulf of Aqaba, Red Sea, Facies, 33, 19-34, https://doi.org/10.1007/BF02537443, 1995.

Heyward, A. J. and Negri, A. P.: Natural inducers for coral larval metamorphosis, Coral Reefs, 18, 273-279, 1999.

Hoey, A. S. and Bellwood, D. R.: Cross-shelf variation in the role of parrotfishes on the Great Barrier Reef, Coral Reefs, 27, 37-47, https://doi.org/10.1007/s00338-007-0287-x, 2007.

Holmes, K. E.: Effects of eutrophication on bioeroding sponge communities with the description of new West Indian sponges, Cliona spp. (Porifera: Hadromerida: Clionidae), Invertebr. Biol., 119, 125-138, https://doi.org/10.1111/j.17447410.2000.tb00001.x, 2000.

Hutchings, P. A.: Biological destruction of coral reefs, Coral Reefs, 4, 239-252, https://doi.org/10.1007/BF00298083, 1986.

Januchowski-Hartley, F. A., Graham, N. A. J., Wilson, S. K., Jennings, S., and Perry, C. T.: Drivers and predictions of coral reef carbonate budget trajectories, P. R. Soc. B, 284, 20162533, https://doi.org/10.1098/rspb.2016.2533, 2017.

Jokiel, P. L. and Coles, S. L.: Response of Hawaiian and other IndoPacific reef corals to elevated temperature, Coral Reefs, 8, 155162, https://doi.org/10.1007/BF00265006, 1990.

Jones, N. S., Ridgwell, A., and Hendy, E. J.: Evaluation of coral reef carbonate production models at a global scale, Biogeosciences, 12, 1339-1356, https://doi.org/10.5194/bg-12-1339-2015, 2015.

Kattan, A., Coker, D. J., and Berumen, M. L.: Reef fish communities in the central Red Sea show evidence of asymmetrical fishing pressure, Mar. Biodivers., 47, 4, 1227-1238, https://doi.org/10.1007/s12526-017-0665-8, 2017.

Kennedy, E. V., Perry, C. T., Halloran, P. R., IglesiasPrieto, R., Schönberg, C. H. L., Wisshak, M., Form, A. U., Carricart-Ganivet, J. P., Fine, M., Eakin, C. M., and Mumby, P. J.: Avoiding Coral Reef Functional Collapse Requires Local and Global Action, Curr. Biol., 23, 912-918, https://doi.org/10.1016/j.cub.2013.04.020, 2013.

Kiene, W. E. and Hutchings, P. A.: Bioerosion experiments at Lizard Island, Great Barrier Reef, Coral Reefs, 13, 91-98, 1994.

Kleemann, K.: The Pectinid Bivalve Pedum spondyloideum (Gmelin 1791): Amount of Surface and Volume Occupied in Host Corals From the Red Sea, Mar. Ecol., 22, 111-133, https://doi.org/10.1046/j.1439-0485.2001.01749.x, 2001.

Kleypas, J., Buddemeier, R., and Gattuso, J.-P.: The future of coral reefs in an age of global change, Int. J. Earth Sci., 90, 426-437, https://doi.org/10.1007/s005310000125, 2001.

Kleypas, J. A., McManus, J. W., and Menez, L. A. B.: Environmental Limits to Coral Reef Development: Where Do We Draw the Line?, Am. Zool., 39, 146-159, 1999.

LaJeunesse, T. C., Parkinson, J. E., Gabrielson, P. W., Jeong, H. J., Reimer, J. D., Voolstra, C. R., and Santos, S. R.: Systematic Revision of Symbiodiniaceae Highlights the Antiquity and Diversity of Coral Endosymbionts, Curr. Biol., 28, 2570-2580, https://doi.org/10.1016/j.cub.2018.07.008, 2018.

Langdon, C., Takahashi, T., Sweeney, C., Chipman, D., Goddard, J., Marubini, F., Aceves, H., Barnett, H., and Atkinson, M. J.: Effect of calcium carbonate saturation state on the calcification rate of an experimental coral reef, Global Biogeochem. Cy., 14, 639-654, https://doi.org/10.1029/1999GB001195, 2000.

Lazar, B. and Loya, Y.: Bioerosion of coral reefs - A chemical approach, Limnol. Oceanogr., 36, 377-383, 1991.
Manzello, D. P.: Ocean acidification hotspots: Spatiotemporal dynamics of the seawater $\mathrm{CO}_{2}$ system of eastern Pacific coral reefs, Limnol. Oceanogr., 55, 239-248, https://doi.org/10.4319/lo.2010.55.1.0239, 2010.

Marshall, A. T. and Clode, P.: Calcification rate and the effect of temperature in a zooxanthellate and an azooxanthellate scleractinian reef coral, Coral Reefs, 23, 218-224, https://doi.org/10.1007/s00338-004-0369-y, 2004.

Marubini, F., Ferrier-Pagès, C., Furla, P., and Allemand, D.: Coral calcification responds to seawater acidification: a working hypothesis towards a physiological mechanism, Coral Reefs, 27, 491-499, https://doi.org/10.1007/s00338-008-0375-6, 2008.

McClanahan, T. R.: Kenyan coral reef lagoon fish: effects of fishing, substrate complexity, and sea urchins, Coral Reefs, 13, 231-241, https://doi.org/10.1007/BF00303637, 1994.

McClanahan, T. R. and Shafir, S. H.: Causes and consequences of sea urchin abundance and diversity in Kenyan coral reef lagoons, Oecologia, 83, 362-370, https://doi.org/10.1007/BF00317561, 1990.

McClanahan, T. R., Nugues, M., and Mwachireya, S.: Fish and sea urchin herbivory and competition in Kenyan coral reef lagoons: the role of reef management, J. Exp. Mar. Biol. Ecol., 184, $237-$ 254, https://doi.org/10.1016/0022-0981 (94)90007-8, 1994.

Metzl, N., Moore, B., Papaud, A., and Poisson, A.: Transport and carbon exchanges in Red Sea Inverse Methodology, Global Biogeochem. Cy., 3, 1-26, https://doi.org/10.1029/GB003i001p00001, 1989.

Moberg, F. and Folke, C.: Ecological goods and services of coral reef ecosystems, Ecol. Econ., 29, 215-233, 1999.

Mokady, O., Lazar, B., and Loya, Y.: Echinoid bioerosion as a major structuring force of Red Sea coral reefs, Biol. Bull., 190, 367372, 1996.

Monroe, A. A., Ziegler, M., Roik, A., Röthig, T., Hardenstine, R. S., Emms, M. A., Jensen, T., Voolstra, C. R., and Berumen, M. L.: In situ observations of coral bleaching in the central Saudi Arabian Red Sea during the 2015/2016 global coral bleaching event, PLoS ONE, 13, e0195814, https://doi.org/10.1371/journal.pone.0195814, 2018.

Orr, J. C., Fabry, V. J., Aumont, O., Bopp, L., Doney, S. C., Feely, R. A., Gnanadesikan, A., Gruber, N., Ishida, A., Joos, F., Key, R. M., Lindsay, K., Maier-Reimer, E., Matear, R., Monfray, P., Mouchet, A., Najjar, R. G., Plattner, G.-K., Rodgers, K. B., Sabine, C. L., Sarmiento, J. L., Schlitzer, R., Slater, R. D., Totterdell, I. J., Weirig, M.-F., Yamanaka, Y., and Yool, A.: Anthropogenic ocean acidification over the twenty-first century and its impact on calcifying organisms, Nature, 437, 681-686, https://doi.org/10.1038/nature04095, 2005.

Osman, E. O., Smith, D. J., Ziegler, M., Kürten, B., Conrad, C., El-Haddad, K. M., Voolstra, C. R., and Suggett, D. J.: Thermal refugia against coral bleaching throughout the northern Red Sea, Glob. Change Biol., 24, e474-e484, https://doi.org/10.1111/gcb.13895, 2018.

Osorno, A., Peyrot-Clausade, M., and Hutchings, P. A.: Patterns and rates of erosion in dead Porites across the Great Barrier Reef (Australia) after 2 years and 4 years of exposure, Coral Reefs, 24, 292-303, https://doi.org/10.1007/s00338-005-0478-2, 2005.

Pari, N., Peyrot-Clausade, M., Le Champion-Alsumard, T., Hutchings, P., Chazottes, V., Gobulic, S., Le Champion, J., and Fontaine, M. F.: Bioerosion of experimental substrates on high 
islands and on atoll lagoons (French Polynesia) after two years of exposure, Mar. Ecol. Prog. Ser., 166, 119-130, 1998.

Perry, C., Edinger, E., Kench, P., Murphy, G., Smithers, S., Steneck, R., and Mumby, P.: Estimating rates of biologically driven coral reef framework production and erosion: a new census-based carbonate budget methodology and applications to the reefs of Bonaire, Coral Reefs, 31, 853-868, https://doi.org/10.1007/s00338-012-0901-4, 2012.

Perry, C. T. and Morgan, K. M.: Bleaching drives collapse in reef carbonate budgets and reef growth potential on southern Maldives reefs, Sci. Rep., 7, 40581, https://doi.org/10.1038/srep40581, 2017.

Perry, C. T., Spencer, T., and Kench, P. S.: Carbonate budgets and reef production states: a geomorphic perspective on the ecological phase-shift concept, Coral Reefs, 27, 853-866, https://doi.org/10.1007/s00338-008-0418-z, 2008.

Perry, C. T., Murphy, G. N., Kench, P. S., Smithers, S. G., Edinger, E. N., Steneck, R. S., and Mumby, P. J.: Caribbean-wide decline in carbonate production threatens coral reef growth, Nat. Commun., 4, 1402, https://doi.org/10.1038/ncomms2409, 2013.

Perry, C. T., Murphy, G. N., Kench, P. S., Edinger, E. N., Smithers, S. G., Steneck, R. S., and Mumby, P. J.: Changing dynamics of Caribbean reef carbonate budgets: emergence of reef bioeroders as critical controls on present and future reef growth potential, P. R. Soc. B, 281, 20142018, https://doi.org/10.1098/rspb.2014.2018, 2014.

Perry, C. T., Morgan, K. M., and Yarlett, R. T.: Reef Habitat Type and Spatial Extent as Interacting Controls on Platform-Scale Carbonate Budgets, Front. Mar. Sci., 185, 1-13, https://doi.org/10.3389/fmars.2017.00185, 2017.

Perry, C. T., Alvarez-Filip, L., Graham, N. A. J., Mumby, P. J., Wilson, S. K., Kench, P. S., Manzello, D. P., Morgan, K. M., Slangen, A. B. A., Thomson, D. P., Januchowski-Hartley, F., Smithers, S. G., Steneck, R. S., Carlton, R., Edinger, E. N., Enochs, I. C., Estrada-Saldívar, N., Haywood, M. D. E., Kolodziej, G., Murphy, G. N., Pérez-Cervantes, E., Suchley, A., Valentino, L., Boenish, R., Wilson, M., and Macdonald, C.: Loss of coral reef growth capacity to track future increases in sea level, Nature, 558, 396400, https://doi.org/10.1038/s41586-018-0194-z, 2018.

Pisapia, C., Burn, D., Yoosuf, R., Najeeb, A., Anderson, K. D., and Pratchett, M. S.: Coral recovery in the central Maldives archipelago since the last major mass-bleaching, in 1998, Sci. Rep., 6, 34720, https://doi.org/10.1038/srep34720, 2016.

Pogoreutz, C., Rädecker, N., Cárdenas, A., Gärdes, A., Voolstra, C. R., and Wild, C.: Sugar enrichment provides evidence for a role of nitrogen fixation in coral bleaching, Glob. Change Biol., 8, 3838-3848, https://doi.org/10.1111/gcb.13695, 2017.

Price, N. N., Martz, T. R., Brainard, R. E., and Smith, J. E.: Diel Variability in Seawater $\mathrm{pH}$ Relates to Calcification and Benthic Community Structure on Coral Reefs, PLoS ONE, 7, e43843, https://doi.org/10.1371/journal.pone.0043843, 2012.

$\mathrm{R}$ Core Team: R: A language and environment for statistical computing, R Foundation for Statistical Computing, Vienna, Austria, available from: http://www.R-project.org/ (last access: 9 July 2018), 2013.

Rädecker, N., Pogoreutz, C., Voolstra, C. R., Wiedenmann, J., and Wild, C.: Nitrogen cycling in corals: the key to understanding holobiont functioning?, Trend. Microbiol., 23, 490-497, https://doi.org/10.1016/j.tim.2015.03.008, 2015.
Raitsos, D. E., Hoteit, I., Prihartato, P. K., Chronis, T., Triantafyllou, G., and Abualnaja, Y.: Abrupt warming of the Red Sea, Geophys. Res. Lett., 38, L14601, https://doi.org/10.1029/2011GL047984, 2011.

Reaka-Kudla, M., Feingold, J., and Glynn, W.: Experimental studies of rapid bioerosion of coral reefs in the Galapagos Islands, Coral Reefs, 15, 101-107, 1996.

Reaka-Kudla, M. L.: The Global Biodiversity of Coral Reefs: A Comparison with Rainforests, in: Biodiversity II: Understanding and Protecting Our Biological Resources, edited by: ReakaKudla, M. L., Wilson, D. E., and Wilson, E. O., The Joseph Henry Press, USA, 83-106, 1997.

Riegl, B.: Climate change and coral reefs: different effects in two high-latitude areas (Arabian Gulf, South Africa), Coral Reefs, 22, 433-446, https://doi.org/10.1007/s00338-003-0335-0, 2003.

Riegl, B. M., Bruckner, A. W., Rowlands, G. P., Purkis, S. J., and Renaud, P.: Red Sea Coral Reef Trajectories over 2 Decades Suggest Increasing Community Homogenization and Decline in Coral Size, PLoS ONE, 7, e38396, https://doi.org/10.1371/journal.pone.0038396, 2012.

Roik, A., Roder, C., Röthig, T., and Voolstra, C. R.: Spatial and seasonal reef calcification in corals and calcareous crusts in the central Red Sea, Coral Reefs, 35, 681-693, https://doi.org/10.1007/s00338-015-1383-y, 2015.

Roik, A., Röthig, T., Roder, C., Ziegler, M., Kremb, S. G., and Voolstra, C. R.: Year-Long Monitoring of Physico-Chemical and Biological Variables Provide a Comparative Baseline of Coral Reef Functioning in the Central Red Sea, PLOS ONE, 11, e0163939, https://doi.org/10.1371/journal.pone.0163939, 2016.

Röthig, T., Ochsenkühn, M. A., Roik, A., van der Merwe, R., and Voolstra, C. R.: Long-term salinity tolerance is accompanied by major restructuring of the coral bacterial microbiome, Mol. Ecol., 25, 1308-1323, https://doi.org/10.1111/mec.13567, 2016.

Sawall, Y. and Al-Sofyani, A.: Biology of Red Sea Corals: Metabolism, Reproduction, Acclimatization, and Adaptation, in: The Red Sea, edited by: Rasul, N. M. A. and Stewart, I. C. F., 487-509, Springer Berlin Heidelberg, available from: http:// link.springer.com/chapter/10.1007/978-3-662-45201-1_28, last access: 7 April 2015.

Sawall, Y., Al-Sofyani, A., Hohn, S., Banguera-Hinestroza, E., Voolstra, C. R., and Wahl, M.: Extensive phenotypic plasticity of a Red Sea coral over a strong latitudinal temperature gradient suggests limited acclimatization potential to warming, Sci. Rep., 5, 8940, https://doi.org/10.1038/srep08940, 2015.

Schmidt, G. M. and Richter, C.: Coral Growth and Bioerosion of Porites lutea in Response to Large Amplitude Internal Waves, PLoS ONE, 8, e73236, https://doi.org/10.1371/journal.pone.0073236, 2013.

Schneider, K. and Erez, J.: The effect of carbonate chemistry on calcification and photosynthesis in the hermatypic coral Acropora eurystoma, Limnol. Oceanogr., 51, 1284-1293, 2006.

Schönberg, C. H. L., Fang, J. K. H., Carreiro-Silva, M., Tribollet, A., and Wisshak, M.: Bioerosion: the other ocean acidification problem, ICES J. Mar. Sci., 74, 895-925, https://doi.org/10.1093/icesjms/fsw254, 2017.

Schuhmacher, H., Loch, K., Loch, W., and See, W. R.: The aftermath of coral bleaching on a Maldivian reef - a quantitative study, Facies, 51, 80-92, https://doi.org/10.1007/s10347005-0020-6, 2005. 
Shamberger, K. E. F., Lentz, S. J., and Cohen, A. L.: Low and variable ecosystem calcification in a coral reef lagoon under natural acidification, Limnol. Oceanogr., 63, 714-730, https://doi.org/10.1002/lno.10662, 2017.

Shaw, E. C., McNeil, B. I., and Tilbrook, B.: Impacts of ocean acidification in naturally variable coral reef flat ecosystems, J. Geophys. Res.-Ocean., 117, C03038, https://doi.org/10.1029/2011JC007655, 2012.

Sheppard, C. and Loughland, R.: Coral mortality and recovery in response to increasing temperature in the southern Arabian Gulf, Aquat. Ecosyst. Health Manag., 5, 395-402, https://doi.org/10.1080/14634980290002020, 2002.

Silbiger, N. J., Guadayol, O., Thomas, F. I. M., and Donahue, M. J.: Reefs shift from net accretion to net erosion along a natural environmental gradient, Mar. Ecol. Prog. Ser., 515, 33-44, https://doi.org/10.3354/meps10999, 2014.

Silverman, J., Lazar, B., and Erez, J.: Community metabolism of a coral reef exposed to naturally varying dissolved inorganic nutrient loads, Biogeochemistry, 84, 67-82, https://doi.org/10.1007/s10533-007-9075-5, 2007.

Steiner, Z., Erez, J., Shemesh, A., Yam, R., Katz, A., and Lazar, B.: Basin-scale estimates of pelagic and coral reef calcification in the Red Sea and Western Indian Ocean, P. Natl. Acad. Sci. USA, 1414323111, https://doi.org/10.1073/pnas.1414323111, 2014.

Steiner, Z., Turchyn, A. V., Harpaz, E., and Silverman, J.: Water chemistry reveals a significant decline in coral calcification rates in the southern Red Sea, Nat. Commun., 9, 3615, https://doi.org/10.1038/s41467-018-06030-6, 2018.

Strahl, J., Stolz, I., Uthicke, S., Vogel, N., Noonan, S. H. C., and Fabricius, K. E.: Physiological and ecological performance differs in four coral taxa at a volcanic carbon dioxide seep, Comp. Biochem. Physiol. A, 184, 179-186, https://doi.org/10.1016/j.cbpa.2015.02.018, 2015.

Tambutté, S., Holcomb, M., Ferrier-Pagès, C., Reynaud, S., Tambutté, É., Zoccola, D., and Allemand, D.: Coral biomineralization: From the gene to the environment, J. Exp. Mar. Biol. Ecol., 408, 58-78, https://doi.org/10.1016/j.jembe.2011.07.026, 2011.

Tribollet, A. and Golubic, S.: Cross-shelf differences in the pattern and pace of bioerosion of experimental carbonate substrates exposed for 3 years on the northern Great Barrier Reef, Australia, Coral Reefs, 24, 422-434, https://doi.org/10.1007/s00338-0050003-7, 2005.

Tribollet, A. and Golubic, S.: Reef Bioerosion: Agents and Processes, in: Coral Reefs: An Ecosystem in Transition, edited by: Dubinsky, Z. and Stambler, N., Springer Netherlands, Dordrecht, 435-449, available from: http://www.springerlink.com/ index/10.1007/978-94-007-0114-4_25 (last access: 7 August 2012), 2011.
Tribollet, A., Decherf, G., Hutchings, P., and Peyrot-Clausade, M.: Large-scale spatial variability in bioerosion of experimental coral substrates on the Great Barrier Reef (Australia): importance of microborers, Coral Reefs, 21, 424-432, https://doi.org/10.1007/s00338-002-0267-0, 2002.

Tribollet, A., Godinot, C., Atkinson, M., and Langdon, C.: Effects of elevated $p \mathrm{CO}_{2}$ on dissolution of coral carbonates by microbial euendoliths, Global Biogeochem. Cy., 23, GB3008, https://doi.org/10.1029/2008GB003286, 2009.

Uthicke, S., Doyle, J., Duggan, S., Yasuda, N., and McKinnon, A. D.: Outbreak of coral-eating Crown-of-Thorns creates continuous cloud of larvae over $320 \mathrm{~km}$ of the Great Barrier Reef, Sci. Rep., 5, 16885, https://doi.org/10.1038/srep16885, 2015.

Vásquez-Elizondo, R. M. and Enríquez, S.: Coralline algal physiology is more adversely affected by elevated temperature than reduced $\mathrm{pH}$, Sci. Rep., 6, 19030, https://doi.org/10.1038/srep19030, 2016.

Vecsei, A.: Fore-reef carbonate production: development of a regional census-based method and first estimates, Palaeogeogr. Palaeocl., 175, 185-200, https://doi.org/10.1016/S00310182(01)00371-6, 2001.

Vecsei, A.: A new estimate of global reefal carbonate production including the fore-reefs, Glob. Planet. Change, 43, 1-18, https://doi.org/10.1016/j.gloplacha.2003.12.002, 2004.

Waldbusser, G. G., Hales, B., and Haley, B. A.: Calcium carbonate saturation state: on myths and this or that stories, ICES J. Mar. Sci. J. Cons., 73, 563-568, https://doi.org/10.1093/icesjms/fsv174, 2016.

Wickham, H. and Chang, W.: ggplot2: An Implementation of the Grammar of Graphics, available from: http://cran.r-project.org/ web/packages/ggplot2/index.html, last access: 9 July 2018.

Wiedenmann, J., D’Angelo, C., Smith, E. G., Hunt, A. N., Legiret, F.-E., Postle, A. D., and Achterberg, E. P.: Nutrient enrichment can increase the susceptibility of reef corals to bleaching, Nat. Clim. Change, 3, 160-164, https://doi.org/10.1038/nclimate1661, 2013.

Zundelevich, A., Lazar, B., and Ilan, M.: Chemical versus mechanical bioerosion of coral reefs by boring sponges lessons from Pione cf. vastifica, J. Exp. Biol., 210, 91-96, https://doi.org/10.1242/jeb.02627, 2007. 